\title{
Influence of Different Surface Pretreatments of Zirconium Dioxide Reinforced Lithium Disilicate Ceramics on the Shear Bond Strength of Self-Adhesive Resin Cement
}

\section{Utjecaj različitih površinskih obrada litij-disilikatne keramike ojačane cirkonijevim dioksidom na smičnu čvrstoću} samoadherirajućega smolastoga cementa

\author{
${ }^{1}$ Dental Polyclinic Zagreb, Department of Prosthodontics, Zagreb \\ Zavod za protetiku Stomatološke poliklinike Zagreb \\ 2 School of Dental Medicine, University of Zagreb, Department of Endodontics and Restorative Dentistry \\ Zavod za endodonciju i restaurativnu stomatologiju Stomatološkog fakulteta Sveučilišta u Zagrebu \\ ${ }^{3}$ School of Dental Medicine, University of Zagreb, Department of Children's and Preventive Dentistry \\ Zavod za dječju i preventivnu stomatologiju Stomatološkog fakulteta Sveučilišta u Zagrebu \\ ${ }^{4}$ School of Dental Medicine, University of Zagreb, Department of Fixed Prosthodontics \\ Odjel fiksne medicine - protetika Stomatološkog fakulteta Sveučilišta u Zagrebu \\ 5 Split-Dalmatia County Health Center, Split, Croatia \\ Dom zdravlja Splitsko-dalmatinske županije, Split
}

\begin{abstract}
Aim: To analyze the influence of different surface pretreatments of zirconium dioxide reinforced lithium disilicate ceramics on the shear bond strength of self-adhesive resin cement. Materials and methods: Eighty-four zirconium reinforced lithium disilicate disc Vita suprinity (Vita Zahnfabrick, Bad Säckingen, Germany) $14 \times 12 \times 2 \mathrm{~mm}$ specimens were fabricated according to the manufacturer's recommendations. The specimens were embedded in acrylic resin blocks and randomly divided in seven groups ( $n=12 /$ each) accorrding to the treatment: Group 1- 10\% hydrofluoric acid; Group 2- silane; Group 3- hydrofluoric and silane; Group 4- sandblasting with silane; Group 5- Er: YAG laser+ silane; Group 6- Nd: YAG laser + silane; and the control group, in which the specimens were not treated. Round shape composite discs (Filtek Bulk fill, 3M ESPE, St.Paul, Minnesota, USA) with $3.5 \mathrm{~mm}$ diameter, were made for shear bond strength testing, and then cemented to the ceramic sample surface using composite cement (RelyX U200 Automix, 3M ESPE, Neuss, Germany). After cementing the composite disc on the sample, the samples were subjected to shear bond strength test of $10 \mathrm{~N}$ with a "stress rate" of $1 \mathrm{MPa} / \mathrm{s}$. To determine the nature of the fracture (adhesive, cohesive or adhesivecohesive), the broken samples were examined under a stereomicroscope. The ANOVA test and the Tukey test were used to compare the values of the bond strength characteristics between different types of materials. All tests were performed with a significance level of $\alpha=0.05$. Results: There was a significant difference in the shear bond strength of self-adhesive cement to dental lithium-disilicate ceramics reinforced with zirconium dioxide after different preparation protocols $(p<0,05)$. The treatment of lithium disilicate ceramics reinforced with zirconium dioxide by silanization, sandblasting + silanization, Nd: YAG + silanization resulted in significantly higher bond strength compared to the control group. There was statistically higher bond strength of self-adhesive cement after pretreatment of lithium disilicate ceramics Nd: YAG + silanization compared to Er: YAG + silanization ( $p$ $<0.05)$. Adhesive fracture dominated in the control group, sandblasting + silanization group, and in the laser groups, while mixed fracture dominated in other groups. Conclusion: Under the limitations of this study, the Nd:YAG irradiation with silanization could be used as pretreatment for providing greater shear bond strength of self-adhesive resin cement to zirconium reinforced lithium disilicate.
\end{abstract}

Received: May 10, 2021

Accepted: August 22, 2021

Address for correspondence Associate professor Andreja Carek, PhD

University of Zagreb

School of Dental Medicine, Department of Fixed Prosthodontics Gundulićeva 5, 10000 Zagreb, Croatia acarek@sfzg.hr

\section{MeSH terms: Self-Curing of} Dental Resins; Surface Properties; Adhesiveness; Shear Strength Author keywords: Laser Irradiation; Surface Treatment; Shear Bond; Surface Roughness; Zirconia Reinforced Lithium Disilicate; Selfadhesive Resin Cement

\section{Introduction}

Due to optical characteristics which are in common with the natural tooth substance and good physical and mechanical properties, dental ceramic materials exhibit chemical stability and excellent biocompatibility with soft tissues, with low plaque adhesion.

\section{Uvod}

Dentalna keramika ima slična optička svojstva kao i prirodna zubna supstancija - kemijsku stabilnost, dobra fizikalna i mehanička svojstva te izvrsnu biokompatibilnost $s$ mekim tkivima s niskom adhezijom plaka. 
Zirconium oxide ceramic materials have excellent mechanical performances, such as high flexural strength (1.0$1.2 \mathrm{GPa})$ and toughness $\left(7-8 \mathrm{MPa} \times \mathrm{m}^{0.5}\right)$. Therefore, they are increasingly used in dental practice, especially in CAD/CAM technology (computer-aided design/computer-aided manufacturing). Zirconium oxide ceramics can be used to make all types of ceramic replacements (crowns, bridges, fixed partial dentures, etc.) The whole procedure, using CAD/CAM technology, is extremely practical and reliable. The zirconia-based core structure is veneered with zirconia veneering ceramics. Both the core and the veneering ceramic have a similar thermal expansion coefficient. In dental practice, clinicians often face a variety of challenges such as choosing the best rehabilitation material when a prosthetic restoration is required on two adjacent teeth - on one zirconium ceramic crown and the other veneer. For esthetic reasons, it would be desirable to use the same type of material, but almost no information is available about zirconia veneering ceramic materials, which have yet to be further explored.

The zirconia-reinforced lithium silicate (ZLS) consists of lithium-metasilicate $\left(\mathrm{Li}_{2} \mathrm{SiO}_{3}\right)$ glass-ceramic and $10 \%$ of zirconium dioxide $\left(\mathrm{ZrO}_{2}\right)$. Ultimately, the crystallization process leads to the fine-grained microstructure formation $\left(\mathrm{Li}_{2} \mathrm{O}-\mathrm{ZrO}_{2}-\mathrm{SiO}_{2}\right)$. $\mathrm{ZLS}$ is also progressively used in $\mathrm{CAD} / \mathrm{CAM}$ technology, thanks to its good mechanical properties and excellent esthetics. Good mechanical properties can be attributed to zirconium dioxide, and esthetics to glassceramics. ZLS can be etched and cemented with adhesive systems, while the same procedure cannot be applied to zirconia restorations. Researchers have proved that the fracture resistance of adhesively cemented, monolithic CAD/CAM fabricated ceramic crowns is remarkably higher compared to conventional cementation (1).

Ceramic restorations have become the "gold standard" for anterior teeth restorations. The shear bond strength of composite cement to previously both etched and silanated porcelain surface surpasses the cohesive porcelain strength. The bonding of composite cement with ceramics is performed in two different ways: mechanically, as a consequence of etching with hydrofluoric acid and the formation of micromechanical retention and chemically, utilizing silane. At the same time, its bonding to enamel is achieved only mechanically. Many researchers encourage porcelain silanization in order to obtain a much stronger connection compared to etching with hydrofluoric acid only, whilst the combination of both is suggested.

The Er: YAG laser acts by thermomechanical ablation vaporizing the water that constitutes the tissues. This vaporization causes an expansion followed by microexplosions, which produces the ejection of both organic and inorganic particles from tissues, promoting the appearance of a dentinal surface with open tubules and without smear layer and an irregular enamel surface, which causes irregularities, thus increasing bond strength (2). Previous studies have already suggested that this laser can be used to create irregularities on the surface of ceramics from different types, and enhance the bond strength between these materials and resin cements $(3,4)$.

Nd:YAG laser modified the external surface of zirconia ceramics and yielded a smooth surface with irregular small
Cirkonij-oksidna keramika ima vrhunska mehanička svojstva, uključujući visoku savojnu čvrstoću $(1,0-1,2 \mathrm{GPa})$ i žilavost $(7-8 \mathrm{MPa} \times \mathrm{m} 0,5)$. Dodatno, razvoj nove tehnologije poput računalno potpomognutog dizajna/računalno potpomognute proizvodnje (CAD/CAM), omogućuje izradu svih keramičkih krunica (ili fiksne djelomične proteze) na bazi cirkonijeva oksida, što čini postupak praktičnijim. Cirkonska jezgra nadomjestka obložena je cirkonskom keramikom koja ima odgovarajući koeficijent termičke ekspanzije jezgri keramike. Kada jedan zub zahtijeva potpuno keramičku krunicu (na bazi cirkonija), a drugi ljusku, kliničari se često suočavaju s izazovom pri odabiru materijala za restauraciju. Iako je poželjno na susjednim zubima koristiti istu obložnu keramiku, malo je dostupnih podataka o cirkonskoj obložnoj keramici.

Litij-silikat ojačan cirkonijevim oksidom (ZLS) temelji se na litij-metasilikatnoj $\left(\mathrm{Li}_{2} \mathrm{SiO}_{3}\right)$ staklokeramici i ojačan je $s$ oko $10 \%$ cirkonijeva dioksida $\left.\left(\mathrm{ZrO}_{2}\right) 30\right)$ koji, nakon konačnoga procesa kristalizacije, potiče stvaranje sitnozrnate mikrostrukture $\left(\mathrm{Li}_{2} \mathrm{O}-\mathrm{ZrO}_{2}-\mathrm{SiO}_{2}\right)$. ZLS pripada novoj generaciji materijala namijenjenih $\mathrm{CAD} / \mathrm{CAM}$ uporabi koji kombinira izvrsna mehanička svojstva cirkonija i visoku estetiku staklokeramike. ZLS se, prema uputama proizvođača, može jetkati i cementirati adhezivnim sustavima, za razliku od cirkonskih nadomjestaka. Dokazano je da je otpornost na pucanje adhezivno cementirane, monolitne keramičke krunice generirane $\mathrm{CAD} / \mathrm{CAM}$-om, znatno veća od one konvencionalno cementirane (1).

Jetkane i silanizirane, porculanske restauracije postale su prvi izbor u estetskoj rehabilitaciji prednjih zuba. Čvrstoća vezivanja kompozitne smole na adekvatno jetkan i silaniziran porculan premašuje kohezijsku čvrstoću porculana. Iako se vezanje na caklinu postiže samo jetkanjem površine radi postizanja mikromehaničke retencije, vezanje $s$ porculanom postiže se i mehanički jetkanjem porculana i kemijski uporabom silanskoga vezivnoga sredstva. Podatci iz literature podupiru silanizaciju porculana koja pruža pouzdaniju vezu od samo jetkanja fluorovodičnom kiselinom, iako se preporučuje kombinacija obaju postupaka.

Er: YAG laser djeluje termomehaničkom ablacijom isparavajući vodu koja čini tkiva. Isparavanje uzrokuje ekspanziju praćenu mikroeksplozijama, što izbacuje organske i anorganske čestica iz tkiva, stvarajući izgled dentinske površine $s$ otvorenim tubulusima i bez zaostatnoga sloja te nepravilnu površinu cakline. Te razne nepravilnosti povećavaju čvrstoću veze (2). U dosadašnjim studijama autori su već sugerirali da se taj laser može koristiti za stvaranje nepravilnosti na površini keramike različitih vrsta te za povećanje čvrstoće veze između tih materijala i smolastih cemenata $(3,4)$.

Nd: YAG laser je, kao posljedicu laserskoga zračenja, modificirao vanjsku površinu keramike i stvorio glatku površinu $s$ nepravilnim, malim pukotinama. Taj nalaz u skladu je $s$ dosadašnjim istraživanjima u kojima je izvješteno o pukotinama na površinama cirkonija nakon laserskoga tretmana $(5,6)$.

Cilj ovog istraživanja bio je analizirati utjecaj različitih površinskih obrada litij-disilikatne keramike ojačane cirkonijevim dioksidom na čvrstoću vezivanja samoadherirajućega smolastoga cementa. 
cracks due to laser irradiation. This finding is in line with the previous studies reporting cracks on zirconia surfaces after laser treatment $(5,6)$.

This study aimed to analyze the effect of different surface pretreatments of zirconium dioxide reinforced lithium disilicate ceramics on the shear bond strength with self-adhesive resin cement.

The null hypothesis was that the shear bond strength of composite self-etching cement to the surface of ZLS after surface treatment with Nd: YAG and Er: YAG laser would be the same as that of conventional preparation protocol (etching with hydrofluoric acid, silanization, sandblasting).

\section{Materials and methods}

\section{Sample preparation}

The material used in this research was lithium disilicate glass-ceramic reinforced with zirconium dioxide (Suprinty, Vita Zahnfabrik, Bad Sackingen, Germany). A total of 70 samples were made for the research purpose and cut into $18 \times 12 \times 2$ size discs in the Isomet 1000 cutter. After cutting the discs, the material was crystallized according to the manufacturer's instructions in the Programat P300 Furnace (Ivoclar Vivadent AG, Schaan, Liechtenstein).

After crystallization, the discs were prepared for polishing by being immersed in a silicone mold to be stationary when polished with 600 grit sandpaper lasting 1 minute for each cause. Polishing was performed at the Department of Materials of the Faculty of Mechanical Engineering and Naval Architecture, in order to make their surface uniform.

After polishing, the samples were embedded in acrylate to completely fix their position when treating the surface.

\section{Pretreatment protocols of lithium disilicate ceramic}

After polishing, the samples were randomly divided into groups depending on the surface treatment method.

In the control group, after polishing with 600 grit sandpaper for a period of 1 minute, the samples were not treated at all.

\section{Group 1 - Hydrofluoric acid}

In the hydrofluoric acid group, the samples were treated with 9.5\% hydrofluoric acid (Bisco Inc., Schaumburg, Illinois, USA) for a period of 90 seconds, whereupon the samples were washed with water and dried according to the manufacturer's instructions.

\section{Group 2 - Silanization}

In the group subjected to the silanization process, the samples were treated with silane (Monobond, Ivoclar Vivadent AG, Schaan, Liechtenstein) for 60 seconds by rubbing silane with a brush on the surface of the sample, according to the manufacturer's instructions.

\section{Group 3-Hydrofluoric acid + Silanization}

In the group subjected to a combination of hydrofluoric acid and silane, the samples were treated with 9.5\% hydrofluoric acid (Bisco Inc., Schaumburg, Illinois, USA) for 90 seconds, whereupon the samples were washed with water and dried according to the manufacturer's instructions, and then treated with silane (Monobond, Ivoclar Vivadent AG,
Nulta hipoteza bila je da nema razlike u veznoj čvrstoći kompozitnoga samojetkajućega cementa na površinu ZLS-a nakon tretiranja površine laserima Nd:YAG i Er:YAG i konvencionalnog protokola pripreme (jetkanje fluorovodičnom kiselinom, silanizacija, pjeskarenje).

\section{Materijal i metode}

\section{Pripremanje uzoraka}

Materijal korišten u ovom istraživanju je litij disilikatna staklokeramika ojačana cirkonijevim dioksidom (Suprinty, Vita Zahnfabrik, Bad Sackingen, Njemačka). Ukupno je za potrebe istraživanja izrađeno 70 uzoraka koji su pripremljeni tako da su u rezalici Isomet 1000 rezani na diskove veličine $18 \times 12 \times 2$. Nakon izrezivanja diskova materijal je kristaliziran prema uputama proizvođača u peći Programat P300 (Ivoclar Vivadent AG, Schaan, Lihtenštajn).

Nakon kristalizacije diskovi su pripremljeni za poliranje uranjanjem u silikonski kalup kako bi bili nepomični pri poliranju brusnim papirom finoće 600 grita u trajanju od jedne minute po pojedinom uzroku. Poliranje je obavljeno u Zavodu za materijale Fakulteta za strojarstvo i brodogradnju kako bi se uniformirala njihova površina.

Nakon poliranja, uzorci su uloženi u akrilat da bi se potpuno fiksirala njihova pozicija pri tretiranju površine.

\section{Protokoli obrade litij-disilikatne keramike}

Nakon poliranja uzorci su nasumično podijeljeni u skupine, ovisno o načinu tretiranja površine.

U kontrolnoj skupini uzorci nakon jednominutnoga poliranja 600-gritnim papirom nisu ni sa čime tretirani.

\section{Skupina 1. - Fluorovodična kiselina}

U skupini tretiranoj fluorovodičnom kiselinom uzorci su 90 sekunda tretirani 9,5-postotnom fluorovodičnom kiselinom (Bisco Inc., Schaumburg, Illionois, SAD) nakon čega su isprani vodom i osušeni prema uputama proizvođača.

\section{Skupina 2. - Silanizacija}

U skupini podvrgnutoj procesu silanizacije uzorci su 60 sekunda tretirani silanom (Monobond, Ivoclar Vivadent AG, Schaan, Lihtenštajn) na način da je silan utrljavan četkicom na površinu uzorka prema uputama proizvođača.

\section{Skupina 3. - Fluorovodična kiselina + silanizacija}

U skupini podvrgnutoj kombinaciji fluorovodične kiseline i silana uzorci su 90 sekunda tretirani 9,5-postotnom fluorovodičnom kiselinom (Bisco Inc., Schaumburg, Illionois, $\mathrm{SAD}$ ) nakon čega su isprani vodom i osušeni prema uputama proizvođača. Zatim su 60 sekunda tretirani silanom (Monobond, Ivoclar Vivadent AG, Schaan, Lihtenštajn) tako da 
Schaan, Liechtenstein) in the duration of 60 seconds in a way that silane was rubbed with a brush on the surface of the sample, according to the manufacturer's instructions.

\section{Group 4 - Sandblasting + silanization}

In the sandblasting group, the samples were sandblasted with $30 \mu \mathrm{m}$ size $\mathrm{Al}_{2} \mathrm{O}_{3}$ particles (CoJet Sand, 3M ESPE, Neuss, Germany) at a pressure of $2.7 \mathrm{~atm}$, and from sandblaster's vertical distance of $1 \mathrm{~cm}$ from the sample in duration of 15 seconds. After sandblasting, the samples were washed under water, dried, and blown off to remove residual particles. The samples were then treated with silane (Monobond, Ivoclar Vivadent AG, Schaan, Liechtenstein) for 60 seconds. Silane was rubbed with a brush on the surface of the sample, according to the manufacturer's instructions.

\section{Group 5-Er: YAG irradiation + silanization}

In the group treated with Er: YAG laser, the samples were treated with a laser (LightWalker, Fotona, Slovenia) of certain parameters: pulse energy of $500 \mathrm{~mJ}$ with a power of 10 $\mathrm{W}$ and a frequency of $4 \mathrm{~Hz}$ for 20 seconds. After laser treatment, the samples were treated with silane (Monobond, Ivoclar Vivadent AG, Schaan, Liechtenstein) for a period of 60 seconds. Silane was rubbed with a brush on the surface of the sample, according to the manufacturer's instructions.

\section{Group 6-Nd: YAG irradiation + silanization}

The group treated with Nd: YAG laser was treated with a laser (LightWalker, Fotona, Slovenia) of the following parameters: $100 \mathrm{~mJ}$ pulse duration, frequency $20 \mathrm{~Hz}$ using a power of $1 \mathrm{~W}$, after which the samples were treated with silane (Monobond, Ivoclar Vivadent AG, Schaan, Liechtenstein) for 60 seconds in a way that silane was rubbed with a brush on the surface of the sample, according to the manufacturer's instructions.

\section{Shear bond strength test}

Before shear bond strength testing, it was necessary to make round shape composite disks (Filtek Bulk fill, 3M ESPE, St.Paul, Minnesota, USA) with a diameter of $3.5 \mathrm{~mm}$, and cement them on the surface of the sample using composite cement (RelyX U200 Automix, 3M ESPE, Neuss, Germany).

After cementing the composite disc on the sample, the samples were subjected to a shear bond strength test at the School of Dental Medicine, University of Zagreb on a testing machine (type LRX with built-in Nexygen programme, Lloyd Instruments, Fareham, United Kingdom) at a test speed of $1 \mathrm{~mm} /$ min. All tests were performed by the same person using force on the sample of $10 \mathrm{~N}$ with a "stress rate" of $1 \mathrm{MPa} / \mathrm{s}$. Specimens were fixed in a testing jig. The load required to debond the specimen was recorded and expressed in MPa by dividing the load by the surface area of the bonded specimen, and the mean shear bond strength for each study group was calculated.

Fracture analysis of the sample surface in order to determine whether it was a cohesive, an adhesive, or a combined fracture were performed at the Department of Materials, Faculty of Mechanical Engineering and Naval Architecture, University of Zagreb using a stereomicroscope Mantis Elite-Cam HD (Vision Engineering Ltd, Woking, Great Britain), 20x optical magnification. je silan utrljavan četkicom na površinu uzorka prema uputama proizvođača.

\section{Skupina 4. - Pjeskarenje + silanizacija}

U skupini podvrgnutoj pjeskarenju uzorci su pjeskareni 15 sekunda česticama $\mathrm{Al}_{2} \mathrm{O}_{3}$ veličine $30 \mu \mathrm{m}$ (CoJet Sand, $3 \mathrm{M}$ ESPE, Neuss, Njemačka) pod tlakom od 2,7 atm s okomite udaljenosti pjeskare od uzorka od $1 \mathrm{~cm}$. Nakon toga oprani su vodom, osušeni te ispuhani kako bi se uklonile zaostatne čestice. Zatim su uzorci tretirani 60 sekunda silanom (Monobond, Ivoclar Vivadent AG, Schaan, Lihtenštajn) tako da je silan utrljavan četkicom na površinu uzorka prema uputama proizvođača.

\section{Skupina 5. - Er:YAG lasersko zračenje + silanizacija}

U skupini tretiranoj Er:YAG laserom uzorci su tretirani laserom (LightWalker, Fotona, Slovenija) određenih parametara: pulsna energija $500 \mathrm{~mJ}$ snage $10 \mathrm{~W}$ te frekvencija $4 \mathrm{~Hz}$ u trajanju od 20 sekunda. Nakon toga su 60 sekunda tretirani silanom (Monobond, Ivoclar Vivadent AG, Schaan, Lihtenštajn) tako da je silan utrljavan četkicom na površinu uzorka prema uputama proizvođača.

\section{Skupina 6. - Nd:YAG lasersko zračenje + silanizacija}

Skupina tretirana Nd:YAG laserom tretirana je uređajem (LightWalker, Fotona, Slovenija) sljedećih parametara: 100 $\mathrm{mJ}$ trajanje pulsa, frekvencija $20 \mathrm{~Hz}$ uz korišstenje snage od 1 W nakon čega su uzorci 60 sekunda tretirani silanom (Monobond, Ivoclar Vivadent AG, Schaan, Lihtenštajn) na način da je silan utrljavan četkicom na površinu uzorka prema uputama proizvođača.

\section{Testiranje smične čvrstoće}

Za testiranje smične čvrstoće prije ispitivanja bilo je potrebno napraviti diskove od kompozita (Filtek Bulk fill, 3M ESPE, St.Paul, Minnesota, SAD) okruglog oblika promjera $3,5 \mathrm{~mm}$ te ih pričvrstiti na površinu uzorka kompozitnim cementom (RelyX U200 Automix, 3M ESPE, Neuss, Njemačka).

Nakon cementiranja kompozitnoga diska na uzorak, uzorci su podvrgnuti ispitivanju smične čvrstoće. Ispitivanje je obavljeno na Stomatološkom fakultetu Sveučilišta u Zagrebu na kidalici (tip LRX s ugrađenim Nexygen programom, Lloyd Instruments, Fareham, Velika Britanija). Testiranje je obavila ista osoba. Trn kidalice nalazi se na spoju staklokeramičkoga uzorka i kompozitnog cementa. Uzorak se zatim do loma opterećuje stalnim pomakom trna od $1 \mathrm{~mm} /$ min (prirast opterećenja od $1 \mathrm{MPa} / \mathrm{s}$ ).

Analiza loma (adhezivni, kohezivni ili adhezivno/kohezivni) učinjena je na slomljenim uzorcima s pomoću stereomikroskopa Mantis Elite-Cam HD (Vision Engineering Ltd, Woking, Velika Britanija) pod povećanjem od 20 puta u Zavodu za materijale Fakulteta strojarstva i brodogradnje Sveučilišta u Zagrebu.

Analiza hrapavosti provedena je u Laboratoriju za precizna mjerenja dužina Fakulteta strojarstva i brodogradnje Sveučilišta u Zagrebu koji djeluje kao Nacionalni laborato- 
Surface roughness measurements were tested on the first, third and fifth samples within the same group, and on each of these samples the measurement was performed on six roughness profiles. A Gaussian filter was used for filtration, the limit value was set to $\lambda c=0.8 \mathrm{~mm}$, the probe radius (r) of $5 \mu \mathrm{m}$, the grading length $(\mathrm{ln})$ of $4.0 \mathrm{~mm}$ and the measuring force $(\mathrm{F})$ of $1.3 \mathrm{mN}$.

The effects of the laser irradiation on a surface of the zirconium reinforced lithium disilicate were examined by scanning electron microscopy (SEM). The SEM analysis was performed at the Department of Materials, Faculty of Mechanical Engineering and Naval Architecture, University of Zagreb. A Tescan Vega TS 5136 MM scanning microscope (TESCAN, Brno, Czech Republic) was used for topographic analysis. The analysis was performed by the same person at $300 \mathrm{x}$ and $1000 \mathrm{x}$ magnifications.

\section{Statistical analysis}

The ANOVA test and the Tukey test were used to compare the values of the bond strength characteristics between different types of materials. The Fisher's exact test was applied to compare the distribution of fracture types between different materials. The analysis was performed using the SAS statistical package on the Windows platform. All tests were performed with a significance level of $\alpha=0.05$.

\section{Results}

For all tested protocols, the distribution did not deviate from the normal distribution (Table 1, $\mathrm{p}>0.05$ ).

Surface roughness analysis has shown that, for both sets of roughness data $(\mathrm{Ra}$ - arithmetic mean deviation of the profile and $\mathrm{Rz}$ - mean height of irregularities), the data distribution did not deviate significantly from the normal distribution ( $p>0.05$ ). rij za duljinu RH. Sva mjerenja obavila je ista osoba kontaktnom metodom i korištenjem mjernog uređaja Perthometer S8P (Feinprüf GmbH, Göttingen, Njemačka). Ispitivanje hrapavosti provedeno je na prvom, trećem i petom uzorku unutar iste skupine, a na svakome od njih mjerenje je provedeno na šest profila hrapavosti. Za filtraciju je korišten Gaussov filtar, granična vrijednost podešena je na $\lambda c=0,8 \mathrm{~mm}$, radijusa $(\mathrm{r})$ ticala od $5 \mu \mathrm{m}$, duljine ocjenjivanja $(\ln )$ od 4,0 $\mathrm{mm}$ te mjerne sile $(\mathrm{F})$ od $1,3 \mathrm{mN}$.

SEM analiza obavljena je u Zavodu za materijale Fakulteta strojarstva i brodogradnje Sveučilišta u Zagrebu. Za topografsku analizu korišten je skeniraući pretražni mikroskop Tescan Vega TS 5136 MM (TESCAN, Brno, Češka Republika) (slika 73.). Analizu je obavila ista osoba na povećanjima od 300 i 1000 puta.

\section{Statistička analiza}

Za usporedbu vrijednosti obilježja snage vezivanja između različitih vrsta materijala korišteni su ANOVA i Tukeyev test za višestruku usporedbu. Za usporedbu distribucije vrste loma između različitih materijala primijenjen je Fisherov egzaktni test. Analiza je obavljena u statističkom paketu SAS na Windowsovoj platformi. Svi testovi rađeni su uz razinu značajnosti $\alpha=0,05$.

\section{Rezultati}

Za sve testirane protokole distribucija ne odstupa od normalne (tablica 1., $\mathrm{p}>0,05$ ).

Analiza hrapavosti pokazuje da za oba skupa podataka za hrapavost ( $\mathrm{Ra}$ - srednje aritmetičko odstupanje profila i $\mathrm{Rz}$ - srednja visina neravnina) distribucija podataka ne odstupa značajno od normalne $(\mathrm{p}>0,05)$.

Table 1 Data normality testing for shear bond strength

Tablica 1. Testiranje normalnosti podataka za snagu vezivanja

\begin{tabular}{|c|c|c|c|c|c|}
\hline \multirow[b]{2}{*}{ Material $\bullet$ Materijal } & \multicolumn{5}{|c|}{ Shear bond strength $\cdot$ Snaga svezivanja } \\
\hline & $\mathbf{N}$ & $\begin{array}{l}\text { Mean val. • } \\
\text { Sr. vr. }\end{array}$ & $\begin{array}{c}\text { Stand dev. } \bullet \\
\text { St. dev. }\end{array}$ & $\mathrm{W}^{* *}$ & $\mathbf{p}^{*}$ \\
\hline Control group $\bullet$ Kontrolna skupina & 5 & 2.51 & 3.11 & 0.83 & 0.14 \\
\hline Acid $\bullet$ Kiselina & 7 & 11.45 & 5.15 & 0.83 & 0.13 \\
\hline Silanization $\bullet$ Silanizacija & 7 & 12.92 & 4.23 & 0.89 & 0.29 \\
\hline Acid + silanization $\cdot$ Kiselina + silanizacija & 7 & 8.92 & 4.09 & 0.95 & 0.74 \\
\hline Sandblasting + silaniz. $\bullet$ Pjeskarenje + silanizacija & 7 & 11.93 & 6.18 & 0.98 & 0.97 \\
\hline $\mathrm{Nd}: Y A G+$ silanization $\bullet \mathrm{Nd}: Y A G+$ silanizacija & 8 & 15.91 & 7.28 & 0.92 & 0.44 \\
\hline Er:YAG + silanization • Er:YAG + silanizacija & 6 & 6.78 & 2.64 & 0.87 & 0.23 \\
\hline
\end{tabular}

\begin{tabular}{|c|c|}
\hline Material $\bullet$ Materijal & Roughness $(\mathrm{Ra}) \bullet$ Hrapavost $(\mathrm{Ra})$ \\
\hline Control group $\bullet$ Kontrolna skupina & 127.8 \\
\hline Acid $\bullet$ Kiselina & 90.2 \\
\hline Silanization $\bullet$ Silanizacija & 75.2 \\
\hline Acid + silanization $\bullet$ Kiselina + silanizacija & 106.8 \\
\hline Sandblasting + silanization $\bullet$ Pjeskarenje + silanizacija & 282.1 \\
\hline $\mathrm{Nd}$ : Yag + silanization $\bullet \mathrm{Nd}$ :Yag + silanizacija & 100.7 \\
\hline Er: Yag + silanization $•$ Er:Yag + silanizacija & 1194.5 \\
\hline
\end{tabular}


Table 2 Shows Ra from a different surface.

Table 3 shows the mean value, standard deviation, median, first quartile, third quartile, minimum and maximum values of shear bond strength between dental lithium disilicate ceramics reinforced with zirconium dioxide and self-adhering composite cement.

Table 4 shows fracture's type share after tested protocols for preparation of lithium disilicate ceramics reinforced with zirconium dioxide.

Figure 1 shows graphically the mean values of shear bond strength with standard deviation after different surface preparation protocols of lithium disilicate ceramics.

The results showed that there was a significant difference in the shear bond strength between self-adhering cement and dental lithium disilicate ceramics reinforced with zirconium dioxide after different preparation protocols $(\mathrm{p}<0.05)$. There was significantly higher shear bond strength after the treatment of lithium disilicate ceramics reinforced with zirconium dioxide by silanization, sandblasting + silanization, Nd: YAG + silanization compared to the control group (in average 12.9 MPA, 11.9 MPa, and 15.9 MPa compared to $2.5 \mathrm{MPa}$ for the control group). The pretreatment of lithium disilicate ceramics with $\mathrm{Nd}$ : YAG + silanization resulted in significantly higher shear bond strength compared to the treatment with Er: YAG + silanization (on average 15.9 MPa compared to $6.8 \mathrm{MPa})(\mathrm{p}<0.05)$.

The fracture type distribution in tested pretreatment protocols is shown in Table 3. Adhesive fracture dominates in the control group (Figure 2) and in the sandblasting + silaniza-
Tablica 2. - različite vrijednosti površinske hrapavosti (Ra), ovisno o načinu predtretmana keramike

Tablica 3. - srednja vrijednost, standardna devijacija, medijan, prvi kvartil, treći kvartil, minimum i maksimum vrijednosti čvrstoće vezivanja između dentalne litij-disilikatne keramike ojačane cirkonijevim dioksidom i samoadherirajućega kompozitnoga cementa

Tablica 4. - udio vrsta loma nakon ispitanih protokola za pripremu litij-disilikatne keramike ojačane cirkonijevim dioksidom

Slika 1. - grafičke srednje vrijednosti vezne čvrstoće sa standardnom devijacijom nakon različitih protokola pripreme površine litij-disilikatne keramike.

Rezultati istraživanja pokazuju da postoji značajna razlika u veznoj čvrstoći samoadherirajućega cementa na dentalnu litij-disilikatnu keramiku ojačanu cirkonijevim dioksidom nakon različitih protokola pripreme $(\mathrm{p}<0,05)$. Zabilježena je značajno veća snaga vezivanja nakon tretmana litij-disilikatne keramike ojačane cirkonijevim dioksidom postupkom silanizacije, pjeskarenjem + silanizacijom i laserom Nd:YAG + silanizacijom u odnosu prema kontrolnoj skupini (u prosjeku 12,9 MPA, 11,9 MPa i 15,9 MPa u odnosu prema 2,5 MPa za kontrolnu skupinu).

Postoji statistički značajno veća vezna čvrstoća samoadherirajućega cementa nakon pretretmana litij-disilikatne keramike laserom Nd:YAG + silanizacijom u usporedbi s laserom Er:YAG + silanizacijom (u prosjeku 15,9 MPa u odnosu prema $6,8 \mathrm{MPa})(\mathrm{p}<0,05)$.

Distribucija vrste loma prema vrsti protokola prikazana je u tablici 4. U kontrolnoj skupini (slika 2.) i u skupini pje-

Table 3 Comparison of shear bond strength for different pretreatment protocols

Tablica 3. Usporedba snage vezivanja za različite protokole obrade

\begin{tabular}{|c|c|c|c|c|c|c|c|c|}
\hline \multirow[b]{2}{*}{ Pretreatment protocol $\bullet$ Protokol obrade } & \multicolumn{7}{|c|}{ Shear bond strength $\cdot$ Snaga vezivanja } & \\
\hline & $\begin{array}{c}\text { Mean value • } \\
\text { Sr. vr. }\end{array}$ & $\begin{array}{c}\text { Stand. dev. } \bullet \\
\text { St. dev. }\end{array}$ & Median & $Q_{1}$ & $\mathbf{Q}_{3}$ & $\begin{array}{l}\text { Minimum • } \\
\text { Minimalan }\end{array}$ & $\begin{array}{l}\text { Maximum • } \\
\text { Maksimalan }\end{array}$ & \\
\hline Control group $\bullet$ Kontrolna skupina & 2.51 & 3.11 & 0.75 & 0.29 & 4.24 & 0.10 & 7.19 & $a b c$ \\
\hline Acid $\bullet$ Kiselina & 11.45 & 5.15 & 10.26 & 9.13 & 13.53 & 5.46 & 21.81 & \\
\hline Silanization $\bullet$ Silanizacija & 12.92 & 4.23 & 14.02 & 8.47 & 17.33 & 7.72 & 17.89 & ${ }^{a}$ \\
\hline Acid + silanization $\bullet$ Kiselina + silanizacija & 8.92 & 4.09 & 7.96 & 4.93 & 13.18 & 3.92 & 14.91 & \\
\hline Sandblasting + silan. $\bullet$ Pjeskarenje + silanizacija & 11.93 & 6.18 & 11.13 & 6.40 & 16.21 & 3.67 & 22.23 & $\mathrm{~b}$ \\
\hline $\mathrm{Nd}: Y A G+$ silanization $\bullet \mathrm{Nd}: Y A G+$ silanizacija & 15.91 & 7.28 & 17.82 & 8.72 & 21.32 & 6.17 & 25.41 & $\mathrm{~cd}$ \\
\hline Er:YAG + silanization • Er:YAG + silanizacija & 6.78 & 2.64 & 5.70 & 5.14 & 9.27 & 4.08 & 10.82 & d \\
\hline
\end{tabular}

a,b,c, ' 'post-hoc' test, the same letter denotes materials that differ from each other • 'post-hoc' test, isto slovo označava materijale koji se uzajamno razlikuju

Table 4 Fracture's type share after tested protocols for preparation of lithium disilicate ceramics reinforced with zirconium dioxide. Tablica 4. Udio vrste loma nakon testiranih protokola za pripremu litij-disilikatne keramike ojačane cirkonijevim dioksidom

\begin{tabular}{|c|c|c|c|c|c|c|c|}
\hline \multirow{3}{*}{ Material $\bullet$ Materijal } & \multicolumn{7}{|c|}{ Fracture type $\bullet$ Vrsta loma } \\
\hline & \multirow{2}{*}{$\begin{array}{c}\text { Total • } \\
\text { Ukupno } \\
\text { N }\end{array}$} & \multicolumn{2}{|c|}{$\begin{array}{l}\text { Adhesive fract. • } \\
\text { Adhezivni lom }\end{array}$} & \multicolumn{2}{|c|}{$\begin{array}{l}\text { Cohesive fract. • } \\
\text { Kohezivni lom }\end{array}$} & \multicolumn{2}{|c|}{$\begin{array}{l}\text { Mixed fracture • } \\
\text { Mješoviti lom }\end{array}$} \\
\hline & & $\mathbf{N}$ & $\%$ & $\mathbf{N}$ & $\%$ & $\mathbf{N}$ & $\%$ \\
\hline Control group $\bullet$ Kontrolna skupina & 5 & 5 & 100.0 & 0 & 0.0 & 0 & 0.0 \\
\hline Acid $\bullet$ Kiselina & 7 & 0 & 0.0 & 1 & 14.3 & 6 & 85.7 \\
\hline Silanization $\bullet$ Silanizacija & 7 & 0 & 0.0 & 0 & 0.0 & 7 & 100.0 \\
\hline Acid + silanization $\bullet$ Kiselina + silanizacija & 7 & 0 & 0.0 & 0 & 0.0 & 7 & 100.0 \\
\hline Sandblasting + silaniz. $\bullet$ Pjeskarenje + silanizacija & 7 & 5 & 71.4 & 1 & 14.3 & 1 & 14.3 \\
\hline Nd:YAG + silanization • Nd:YAG + silanizacija & 8 & 4 & 50.0 & 1 & 12.5 & 3 & 37.5 \\
\hline Er:YAG + silanization • Er:YAG + silanizacija & 6 & 2 & 33.3 & 0 & 0.0 & 4 & 66.7 \\
\hline
\end{tabular}



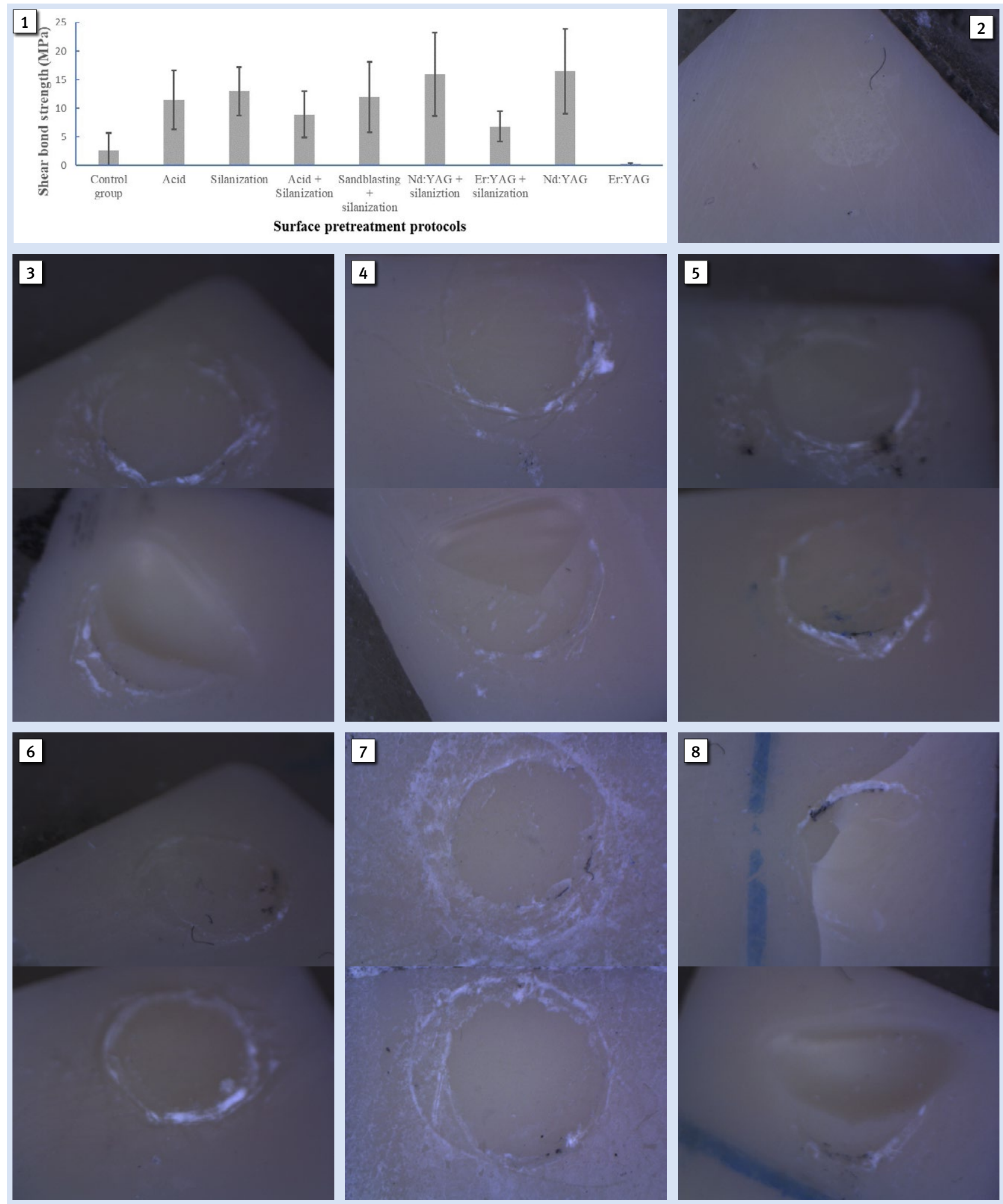

Figure 1 Shear bond strength of lithium disilicate ceramic to a selfadhesive cement after its different surface pretreatment

Slika 1. Snaga vezivanja samoadherirajućega cementa na litijdisilikatnu keramiku nakon različitih površinskih tretmana

Figure 2 Adhesive fracture in the control group

Slika 2. Adhezivna fraktura u kontrolnoj skupini

Figure 3 Adhesive fracture in the sandblasting + silanization group

Slika 3. Adhezivna fraktura u skupini pjeskarenje + silanizacija

Figure 4 Mixed fracture in the acid

Slika 4. Mješoviti lom u skupini tretiranoj kiselinom
Figure 5 Mixed fracture in silanization

Slika 5. Mješovita fraktura u silaniziranoj skupini

Figure 6 Mixed fracture in acid + silanization

Slika 6. Mješovita fraktura u skupini kiselina + silanizacija

Figure 7 Mixed fracture in Er: YAG + silanization group

Slika 7. Mješovita fraktura u skupini Er: YAG + silanizacija

Figure 8 Adhesive fracture in $\mathrm{Nd}$ : YAG

Slika 8. Adhezivna fraktura u skupini tretiranoj Nd: YAG laserom 

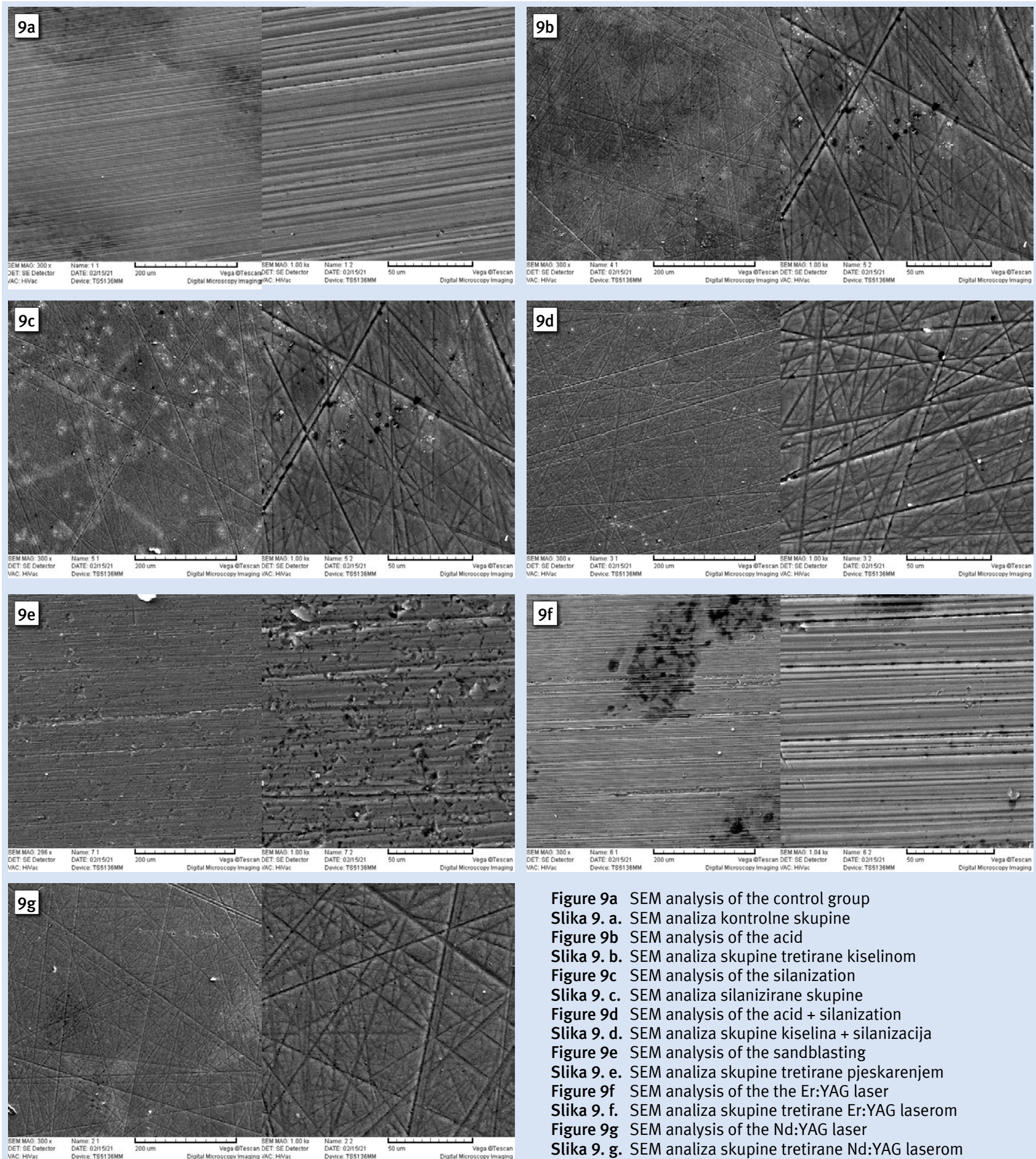

Figure 9a SEM analysis of the control group

Slika 9. a. SEM analiza kontrolne skupine

Figure $9 \mathrm{~b}$ SEM analysis of the acid

Slika 9. b. SEM analiza skupine tretirane kiselinom

Figure 9c SEM analysis of the silanization

Slika 9. c. SEM analiza silanizirane skupine

Figure 9d SEM analysis of the acid + silanization

Slika 9. d. SEM analiza skupine kiselina + silanizacija

Figure 9e SEM analysis of the sandblasting

Slika 9. e. SEM analiza skupine tretirane pjeskarenjem

Figure $9 f$ SEM analysis of the the Er:YAG laser

Slika 9. f. SEM analiza skupine tretirane Er:YAG laserom

Figure $9 \mathrm{~g}$ SEM analysis of the $\mathrm{Nd}$ :YAG laser

Slika 9. g. SEM analiza skupine tretirane Nd:YAG laserom

tion group (Figure 3), while in the acid (Figure 4), silanization (Figure 5), acid + silanization (Figure 6), and Er: YAG + silanization group (Figure 7) mixed fracture dominates. In group Nd: YAG, the adhesive fracture also dominates (Figure 8 ), but with a share of $50 \%$, while the share of mixed fracture is $37.5 \%$.

Topographic architecture after surface treatment with different processing methods at magnifications of 300 and 1000 $\mathrm{x}$ was reviewed by SEM analysis.

Figure 9 SEM analysis after surface treatment with different processing methods skarenje + silanizacija (slika 3.) prevladava adhezivni lom, a u skupinama kiselina (slika 4.), silanizacija (slika 5.), kiselina + silanizacija (slika 6.) i Er:YAG + silanizacija (slika 7.) prevladava mješoviti. U skupini Nd:YAG također prevladava adhezivni lom (slika 8.), ali s udjelom od $50 \%$, a udio mješovitoga loma je $37,5 \%$.

Topografska arhitektura nakon tretiranja površine različitim načinima obrade na povećanjima od 300 i 1000 puta pregledana je SEM analizom.

Slika 9. - SEM analiza nakon površinske obrade različitim metodama 


\section{Discussion}

Despite continuous development and technological innovations, there is no material that is perfect on the market; therefore it is important to mention the shortcomings and complications in the therapy with these materials that occur due to fracture of the restoration, cement loosening, hypersensitivity, or abutment tooth caries. To ensure the durability and favorable biomechanics of such a ceramic appliance, its surface must be treated with chemical agents prior to cementing to the abutment tooth of the fixed prosthetic appliance. Technology development raises the question of the use of alternative systems that can affect the treatment and the roughness of the surface of ceramic material by acting on the shear bond strength of ceramics with dental cement. The use of dental laser is one of such alternative systems. Dental lasers are increasingly used in dental medicine, which places this area of research in the scientist's focus.

Although dental laser has been used for industrial purposes for a long period of time, its surface preparation is more recent. Laser preparation can change the surface microstructure of many materials and can be easily controlled $(7,8)$.

Previous research has shown that certain types of lasers, adjusted to certain parameters, can affect the surface roughness and characteristics of the material, thus directly affecting the shear bond strength system of ceramics. The energy released by laser can have beneficial effects on surface roughness by creating microcracks, thus forming an additional retention surface and improving the shear bond strength. However, laser-generated energy can also reduce the quality of the bond by dissolving the ceramic surface. In accordance with the newly created, smooth, dental surface of ceramic material, the laser reduces the shear bond strength. Ural and Kalyoncuoglu proved this in their research in 2012 by treating the surface of zirconium oxide ceramics with a CO2 laser. They observed that increasing the laser output power led to a decrease in the shear bond strength potential due to molten area formation on the ceramic surface (9).

A similar result was obtained by Hoosmand in 2015 using a Nd: Yag laser (shear bond strength potential weakening by creating molten areas on the ceramic surface), while Akin et al. showed that the Er: Yag laser had a beneficial effect on the shear bond strength creating microcracks and additional retention surfaces (10). It can be concluded that lasers and their influence on the shear bond strength when treating the dental ceramic's surface are unpredictable. The multitude of variables in the dental ceramics system, a large number of laser parametric combinations and the laser's surface length treatment provide research breadth, numerous opportunities for new observations, and innovativeness of the obtained results of individual research.

By standardizing the parameters for individual lasers, certain types of dental ceramics and variables responsible for shear bond strength, there will be a better understanding of bonding and processes that contribute to, or lead to bond failure, which is especially important to clinical work, thus ensuring quality and longevity of prosthetic therapy.

This study aimed to analyze the shear bond strength of self-adhering composite cement (RelyX U200 Automix, 3M,

\section{Rasprava}

Unatoč kontinuiranom razvoju i tehnološkim inovacijama, na tržištu još nema idealnoga gradivnog materijala tako da je važno spomenuti nedostatke i komplikacije u terapiji tim materijalima koje nastaju zbog puknuća nadomjestka, popuštanja cementa, preosjetljivosti ili karijesa uporišnog zuba. Kako bi se osigurala trajnost i povoljna biomehanika takva keramičkoga rada, njegova se površina mora tretirati kemijskim agensima prije nego li bude cementiran na zub nosač fiksnoprotetičkoga rada. Razvojem tehnologije postavlja se pitanje upotrebe alternativnih sustava koji mogu utjecati na obradu i hrapavost površine keramike djelujući na veznu čvrstoću keramike s dentalnim cementom. Jedan od takvih alternativnih sustava jest i dentalni laser koji se sve češće upotrebljva u dentalnoj medicini čime i to područje istraživanja dolazi u fokus znanstvenika.

Iako se laser već dulje primjenjuje u industrijske svrhe, priprema površine laserom novijeg je datuma. Riječ je o postupku kojim se može mijenjati mikrostruktura površina mnogih materijala i koji je moguće jednostavno kontrolirati $(7,8)$

Dosadašnja istraživanja pokazala su da pojedine vrste lasera, podešene na određene parametre, mogu utjecati na površinsku hrapavost i svojstva materijala i tako izravno utjecati na veznu čvrstoću keramičkoga sustava. Energija koju laser oslobađa može korisno utjecati na površinsku hrapavost stvarajući mikropukotine čime nastaje dodatna retencijska površina i poboljšava se vezna čvrstoća. No laserom stvorena energija može i smanjiti kvalitetu veze djelujući tako da rastali površinu keramike i, sukladno novonastaloj glatkoj površini keramičkoga materijala, smanji veznu čvrstoću. To su 2012. godine dokazali Ural i Kalyoncuoglu u svojem istraživačkom radu tretirajući površinu cirkonij-oksidne keramike $\mathrm{CO}_{2}$ laserom. Uočili su da povećanje izlazne snage lasera smanjuje potencijal vezne čvrstoće zbog stvaranja rastaljenih područja na površini keramike (9).

Sličan rezultat dobio je i Hoosmand 2015. godine koristeći se Nd:Yag laserom (slabljenje potencijala vezne čvrstoće zbog stvaranja rastaljenih područja na površini keramike), a Akin i suradnci u svojoj su studiji pokazali da Er:Yag laser povoljno utječe na veznu čvrstoću stvarajući mikropukotine i dodatne retencijske površine (10). Iz ovoga se može zaključiti da su laseri i njihov utjecaj na veznu čvrstoću pri obradi površine dentalne keramike vrlo nepredvidivo područje rada. Mnoštvo varijabli u sustavu dentalnih keramika, velik broj parametarskih kombinacija lasera i duljine laserskoga tretiranja površine daju istraživačku širinu i mnogobrojne mogućnosti za nova zapažanja i inovativnost dobivenih rezultata pojedinog istraživanja.

Standardizacijom parametara za pojedine lasere, pojedine vrste dentalnih keramika te varijabli odgovornih za veznu čvrstoću, bolje će se shvatiti načini vezivanja i procesi koji tomu pridonose ili dovode do kolapsa veze, što je posebno važno za klinički rad i osiguravanje kvalitete i dugotrajnosti protetičke terapije.

Svrha ovoga istraživanja bila je ispitati veznu čvrstoću samoadherirajućega kompozitnoga cementa (RelyX U200 Automix, 3M, ESPE, Neuss, Njemačka) na površinu staklo- 
ESPE, Neuss, Germany) to the surface of glass ceramics reinforced with zirconium oxide (Suprinity, Vita Zahnfabrik, Bad Sackingen, Germany) after different surface pretreatments. The aim of the survey was also to examine the effect of laser radiation (Er: YAG, Nd: YAG) on the surface (qualitative micromorphological analysis of the ceramics surface samples using SEM, microchemical X-ray spectroscopy using EDS and X-ray diffraction analysis, XRD), surface roughness (profilometry) and samples shear strength with fracture analysis and to compare with conventional surface preparation protocols (sandblasting, etching with hydrofluoric acid, silanization).

After the process of controlled glass crystallization, the introduction and invention of glass- ceramics, from the first Nycor glass through leucite (IPS Empress) and ceramics with mica crystals (Dicor ceramics), then lithium disilicate (IPS Empress 2 and E-max ceramics) and finally hybrid, lithium disilicate glass-ceramics reinforced with zirconium dioxide have occurred in a relatively short period. Leucite glass-ceramics were used to make individual crowns in the anterior (layering technique) or posterior (staining technique) segment of dentition and onlay, inlay, and overlay. It was quickly noticed that such a narrow indication area, which characterized both first generations of glass-ceramics, was not profitable. Therefore, various attempts were made to strengthen glass-ceramics with the intention of using it for greater constructions. The crystal structure, quantity, arrangement, and crystals size were changed; secondary phases were introduced until the final reinforcement with zirconium oxide. Such a combination resulted in very desirable building material in fixed prosthetic therapy that combines good properties of glass-ceramics (the possibility of achieving excellent esthetics) and zirconium oxide (outstanding mechanical properties). Ensuring a quality connection between the restoration and the abutment tooth can be observed through two aspects: prosthetic appliance surface preparation made of ceramic material and abutment tooth surface preparation. The inner surface of ceramics must be conditioned to ensure optimal micro-mechanical retention by penetrating the composite into the ceramic micro-roughness surface; this procedure increases the cement mechanical retention by increasing the contact surface with the tooth structure through the microporosity formation. Roughness formation and promotion of micro-mechanical retention, different ways of surface treatment in contact such as abrasive treatment, sandblasting, and acid etching have been well explained in the literature (11, 12). These procedures were tested in in vitro studies. In vitro studies and the results obtained by such studies have their limitations; therefore it is necessary to take them with reserve. As much as in vitro research can simulate conditions in the oral cavity, it is still difficult to obtain identical conditions since the oral cavity is a specific and complex medium from both a mechanical and a corrosive point of view. However, in vitro studies are easier to conduct, and they are also cheaper and faster. Their results can be used as a guide to help interpret with considerable certainty a wide range of developments in the oral cavity. This attitude is widely accepted in the scientific community. keramike ojačane cirkonijevim oksidom (Suprinity, Vita Zahnfabrik, Bad Sackingen, Njemačka) nakon različitih načina obrade površine keramike te ispitati utjecaj laserskoga zračenja (Er:YAG, Nd:YAG) na površinu (kvalitativna mikromorfološka analiza površine keramičkih uzoraka upotrebom SEM-a, mikrokemijska rendgenska spektroskopija upotrebom EDS-a te rendgenska difrakcijska analiza, XRD), površinsku hrapavost (profilometrija) te smičnu čvrstoću uzoraka s analizom loma i usporediti s konvencionalnim protokolima pripreme površine (pjeskarenje, jetkanje fluorovodičnom kiselinom, silanizacija).

Otkako se primjenjuje postupak kontrolirane kristalizacije stakla i otkako se proizvodi staklokeramika, od prvoga Nycor stakla preko leucitne (IPS Empress) i keramike s kristalima tinjca (Dicor keramike), zatim litij-disilikatne (IPS Empress 2 i E-max keramike) i konačno hibridne litij-disilikatne staklokeramike ojačane cirkonijevim dioksidom, prošlo je razmjerno malo vremena, ali je prijeđeni put pun spoznaja. Leucitne staklokeramike koristile su se za izradu pojedinačnih krunica u prednjem (tehnika slojevanja) ili stražnjem (tehnika bojenja) segmentu zubnog niza te onlaya, inlaya te overlaya. Vrlo brzo uočeno je da takvo suženo indikacijsko područje, koje je obilježavalo obje prve generacije staklokeramike, nije rentabilno te se pokušalo različitim načinima ojačati staklokeramiku kako bi se mogla upotrijebiti i za veće konstrukcije. Mijenjala se kristalna struktura, količina, raspored i veličina kristala, uvedene su sekundarne faze i konačno je ojačana cirkonijevim oksidom. Takvom kombinacijom dobiven je vrlo poželjan gradivni materijal u fiksnoprotetičkoj terapiji koji objedinjuje dobra svojstva staklokeramike (mogućnost postizanja izvrsne estetike) i cirkonijeva oksida (izvanredna mehanička svojstva).

Osiguranje kvalitetne veze između nadomjestka i uporišnog zuba može se promatrati $s$ dva aspekta: pripreme površine protetičkoga rada izrađenoga od keramičkoga materijala i pripreme površine uporišnog zuba. Unutarnja površina keramičkoga rada mora se kondicionirati kako bi se osigurala optimalna mikromehanička retencija penetracijom kompozita u mikrohrapavost površine keramike. Taj postupak povećava mehaničku retenciju cementa povećavajući kontaktnu površinu sa strukturom zuba tvorbom mikroporoziteta. Tvorba hrapavosti i promocija mikromehaničke retencije, različiti načini obrade površina u kontaktu poput obrade brusnim sredstvom, pjeskarenjem i jetkanje kiselinama, dobro je obrađeno u literaturi $(11,12)$. Svi ti postupci testirani su u istraživanjima in vitro. Nužno je upozoriti na ograničenja studija in vitro te na rezultate dobivene u takvim istraživanjima i potrebno ih je uzeti s određenom suzdržanošću. Koliko god istraživanja in vitro mogu simulirati uvjete u usnoj šupljini, ipak je teško postići jednake uvjete jer je usna šupljina specifičan i vrlo složen medij, kako s mehaničkoga tako is korozivnoga stajališta. No istraživanja in vitro jednostavnija su za provedbu, jeftinija i brža. Njihovi rezultati mogu upućivati, i sa značajnom sigurnošću biti implementirani, na zbivanja u usnoj šupljini. Takvo stajalište široko je prihvaćeno u znanstvenoj zajednici.

Tian navodi da je najčešće korištena tehnika pripreme površine staklokeramičkoga nadomjestka prije cementira- 
Tian has stated that the most commonly used technique for preparing the surface of a glass-ceramic restoration before cementation is treatment with hydrofluoric acid and silanization (13). During this procedure, the surface was partially dissolved and the crystals were partially stripped, leading to a rough ceramic surface formation that provided micromechanical retention with the composite cement. An additional roughness increase enlarges the surface energy and interaction between the binder and silane, which promoted the chemical-mechanical adhesion between the ceramic / silane/cement surface (14). While hydrofluoric acid increases the shear bond strength between cement and ceramics, the acid simultaneously reduces the material mechanical resistance depending on the acid concentration and the conditioning time. These factors can also change the shear bond strength between composite cement and glass-ceramics (15).

Cement should ensure good replacement retention and quality edge fitting, but its contribution to modern building materials application is certainly in providing better optical properties of prosthetic appliance. The first types of cements were aqueous suspensions, such as zinc phosphate and glassionomer cement. By introducing composite cement, properties such as solubility and adhesion have been improved by enabling a minimally invasive abutment tooth preparation form. The esthetic property of composite cement is of great importance in modern esthetic prosthetics; therefore composite cement is becoming more and more common in dental medicine. It consists of three parts: an organic resin matrix consisting of bis-GMA or urethane-dimethacrylates (UDMA), inorganic filler particles, and a binder (bonding intermediate layer). They are characterized by high compressive and tensile strength, the ability to achieve a micromechanical bond with enamel, dentin, dental alloys, and ceramics. Composite cement together with an adhesive bonding system makes up adhesive cementation. The bond achieved by adhesive cementation can be mechanical, micromechanical, and chemical at the molecular level.

The results of this study showed that the best shear bond strength was achieved after surface treatment with $\mathrm{Nd}$ : Yag laser in combination with silanization, while the application of Er: Yag laser has achieved lower values of shear bond strength compared to conventional surface preparation methods (sandblasting, etching, silanization), which makes the second null hypothesis (no difference in shear bond strength between laser-treated surfaces and conventional surface treatment methods) rejected, while the second working hypothesis (shear bond strength is higher after laser treatment) is partially accepted. The largest contact area was obtained in samples treated with Nd: Yag laser.

Scanning electron microscopy analysis of fractured surfaces showed the adhesive type of fractures (largest in samples sandblasting + silanization, absent in samples treated with acid, silanization, and acid + silanization), cohesive type of fracture (same within samples treated with acid, sandblasting + silanization, and $\mathrm{Nd}$ : laser + silanization, while in other samples this type of fracture did not occur) and mixed type of fracture (highest in samples treated with silanization and acid nja tretiranje florovodičnom kiselinom i silanizacijom (13). U tom postupku površina je djelomično otopljena i kristali su dijelom ogoljeni, što je poticalo stvaranje hrapave površine na keramici koja je osiguravala mikromehaničku retenciju s kompozitnim cementom. Dodatnim povećanjem hrapavosti raste površinska energija i interakcija između veznoga sredstva i silana, što je promoviralo kemijsko-mehaničku adheziju između keramike/silana/cementne površine (14). Dok fluorovodična kiselina povećava veznu čvrstoću između cementa i keramike, kiselina istodobno smanjuje mehaničku otpornost materijala, ovisno o koncentraciji kiseline i duljini kondicioniranja. Ti čimbenici mogu također mijenjati veznu čvrstoću između kompozitnoga cementa i staklokeramike (15).

Cement bi trebao osigurati dobru retenciju nadomjestka i kvalitetno rubno prilijeganje, ali njegov doprinos u primjeni suvremenih gradivnih materijala svakako je i u osiguranju boljih optičkih svojstava protetičkoga rada. Prvi cementi bili su vodene suspenzije, poput cink-fosfatnih i stakloionomernih cemenata. Uvođenjem kompozitnih cemenata, svojstva poput rastvorljivosti $\mathrm{i}$ adhezije poboljšana su i omogućuju minimalno invazivan preparacijski oblik uporišnoga zuba. Estetsko svojstvo kompozitnih cemenata vrlo je važno u suvremenoj estetskoj protetici i zato taj materujl postaje sve zastupljeniji u dentalnoj medicini. Tvore ga tri dijela: organska smolasta matrica koju čine bis-GMA ili uretan-dimetakrilati (UDMA), anorganske čestice punila te vezujuće sredstvo (spojni međusloj). Karakterizira ih velika tlačna i vlačna čvrstoća, moguće postizanje mikromehaničke veze $s$ caklinom, dentinom, dentalnim legurama i keramikama. Kompozitni cement, zajedno s adhezijskim sustavom veze, čini adhezijsko cementiranje. Veza koju je moguće postići adhezijskim cementiranjem jest mehanička, mikromehanička i kemijska na molekularnoj razini.

Rezultati ovog istraživanja pokazuju da je najbolja vezna čvrstoća postignuta nakon tretiranja površine Nd:Yag laserom u kombinaciji sa silanizacijom, a da primjena Er:Yag lasera ostvaruje niže vrijednosti vezne čvrstoće u odnosu prema konvencionalnim načinima pripreme površine (pjeskarenje, jetkanje, silanizacija), čime se odbacuje druga nulta hipoteza (nema razlike u veznoj čvrstoći između površina obrađenih laserom i konvencionalnih načina obrade površine), a djelomično se prihvaća druga radna hipoteza (vezna čvrstoća veća je nakon tretmana laserom). Istaknimo da je u ovom istraživanju dobivena najveća kontaktna površina na uzorcima tretiranima Nd:Yag laserom.

Analiza pretražne elektronske mikroskopije frakturiranih površina upućuje na to da se radi o adhezivnom lomu (najveći kod uzoraka pjeskarenje + silanizacija, nema ga na uzorcima tretiranima kiselinom, silanizacijom i kiselinom + silanizacijom) i kohezivnom tipu loma (jednak kod uzoraka tretiranih kiselinom, pjeskarenjem + silanizacijom te $\mathrm{Nd}$ :Yag laserom + silanizacijom, a u ostalim uzorcima nije se dogodila ta vrsta loma) i mješovitom tipu loma (najveći na uzorcima tretiranima silanizacijom te kiselinom i silanizacijom, a u kontrolnoj skupini nema te vrste loma).

$\mathrm{Na}$ kvalitetu veze, odnosno na veznu čvrstoću staklokeramike i kompozitnoga veznoga sredstva, utječe niz čimbenika. Svi imaju jedan imperativ - postići kvalitetnu vezu koja osi- 
+ silanization, while in the control group there were no fractures of this type).

The quality of the bond, i.e. the shear bond strength of the glass-ceramic and composite bonding agent, is influenced by numerous factors. The imperative is known to everyone to achieve a quality bond that ensures the durability of prosthetic appliance. Different methods of glass-ceramic surface treatment before cementation have been described in the literature and applied in clinical work, all of them aimed to achieve the best possible bond between the restoration and the abutment tooth. The most common way to test the bond strength is the shear test. This test shows the occurrence of cohesive fracture within a material more often than at the junction of two materials. The result is explained by the strong stress accumulation during testing which can lead to test results misinterpretation. Consequently, it is important to eliminate uneven stress within the adhesive zone. Some authors have used very small test areas of only $1 \mathrm{~mm}^{2}$ to create a uniformly transmitted stress to the joint surface $(16,17$, 18). In this way, detection of the weakest points of the procedure is enabled. In the machine production process of restoration, the impact of this procedure on the cutting surfaces should be taken into consideration. The milled sample's SEM analysis shows visible crystals on the cutting surface, which improve micromechanical retention and increase the bonding surface with composite cement. These results were confirmed by this study. This interpretation confirms the hypothesis that it may be possible to establish a quality bond with glass-ceramic chains without etching with hydrofluoric acid (16). Pollington has claimed that SEM analysis of machine processed lithium-disilicate glass-ceramics surface revealed the presence of microporosity which may be of significant importance in achieving a micromechanical bond between the restoration and the abutment tooth surface. $\mathrm{He}$ pointed out that this type of complete ceramic must be subjected to additional surface treatment procedures to provide sufficient micro retention for quality bond achievement (19). If a cohesive fracture of the binder dominates, it occurs due to microcracks inside the cement rather than the intermediate joint itself.

Silane use as a bond promoter between the ceramics and the binder is a well-known fact (20). The bond with the ceramics is achieved through a condensation reaction between silanol groups $(\mathrm{Si}-\mathrm{OH})$ on the ceramic surface and hydrolyzed silane silanol groups, which forms a siloxane bond ( $\mathrm{Si}-\mathrm{O}-\mathrm{Si}$ ) and produces a water molecule as a by-product (21). The presence of a glassy phase in ceramics promotes forming of a better siloxane bond. The silanol groups then react by forming a siloxane network with silicon on the surface (22). An important factor in the chemical bond between the two materials is silicon from glass. This finding by Pollington is consistent with an earlier claim that etching is not necessary (19).

Mean roughness value and SEM analysis showed an irregular surface with pronounced porosity and undermined sites. This surface is visibly weakened by the action of hydrofluoric acid. This is also confirmed by other authors (23).

Glass-ceramics sandblasting leads to extreme destruction of glass and crystals. The crystals obliterate dentinal tubules gurava trajnost protetičkoga rada. U literaturi su opisani, a u kliničkom radu primjenjivani, različiti načini obrade površine staklokeramike prije cementiranja, svi u svrhu postizanja što kvalitetnije veze između nadomjestka i uporišnoga zuba. Najčešći način ispitivanja vezne čvrstoće jest smični test. On vrlo često pokazuje nastajanje kohezivnoga loma unutar materijala, znatno češće nego na spoju dvaju materijala. Taj rezultat objašnjava se izrazitim skupljanjem naprezanja tijekom testiranja, što može rezultirati pogrešnom interpretacijom rezultata testiranja. Zato bi bilo važno eliminirati neujednačeno naprezanje unutar adhezivne zone. Neki autori koriste se vrlo malim područjima testiranja od samo $1 \mathrm{~mm}^{2}$ kako bi stvorili naprezanje koje se ujednačeno prenosi na spojnu površinu $(16,17,18)$. Na taj način omogućena je najjednostavnija detekcija najslabije karike u tom procesu. $\mathrm{U}$ postupku strojne izrade nadomjestaka mora se uzeti u obzir i sam utjecaj tog postupka na rezne površine. SEM analiza izglodanoga uzorka pokazuje da su na reznoj površini vidljivi kristali koji će poboljšati mikromehaničku retenciju i povećati površinu za vezivanje $s$ kompozitnim cementom, što je potvrđeno i u ovom istraživanju. To tumačenje može potvrditi hipotezu da je možda moguće kod lančanih staklokeramika uspostaviti kvalitetnu vezu i bez jetkanja fluorovodičnom kiselinom (16). Pollington nadalje tvrdi da je SEM analiza strojno obrađene površine litij-disilikatne staklokeramike otkrila mikroporozitet koji može biti vrlo važan u postizanju mikromehaničke veze između nadomjestka i površine uporišnoga zuba. Istaknuo je da je tu vrstu potpune keramike nužno podvrgnuti dodatnim postupcima obrade površine da bi se osiguralo dovoljno mikroretencije za postizanje kvalitetne veze (19). Ako prevladava kohezivni lom veznoga sredstva, tada su razlog za to mikropukotine unutar cementa, a ne sam međuspoj.

Upotreba silana kao promotora veze između keramike i veznoga sredstva dobro je poznata činjenica (20). Veza s keramikom ostvaruje se kondenzacijskom reakcijom između silanolnih grupa $(\mathrm{Si}-\mathrm{OH})$ na površini keramike i silanolnih grupa hidroliziranoga silana, što tvori siloksansku vezu (Si-O-Si) i producira molekulu vode kao nusprodukt (21). Staklasta faza u keramici pospješuje ostvarivanje boljih siloksanskih veza. Silanolne skupine zatim reagiraju dalje tvoreći siloksansku mrežu sa silicijem na površini (22). Silicij iz stakla važan je čimbenik kemijske veze između dvaju materijala. Takav Pollingtonov nalaz u skladu je s ranijom tvrdnjom da jetkanje nije nužno (19).

Srednja vrijednost hrapavosti i SEM analiza pokazale su nepravilnu površinu s izraženim porozitetom i potkopanim mjestima. Takva površina vidljivo je oslabljena djelovanjem fluorovodične kisline. To potvrđuju i drugi autori (23).

Pjeskarenje staklokeramike rezultira izrazitom destrukcijom stakla i kristala koja može biti vrlo velika. Kristali obliteriraju dentinske tubuluse pa je nemoguće osigurati kvalitetnu vezu. Drugi razlog za lošu vezu jest kontaminacija i odlaganje čestica aluminijeva oksida na površini keramike koje također mogu kompromitirati vezu. Ustun i suradnici tvrde da obrada površine utječe na površinsku hrapavost te navode da se pjeskarenjem ostvaruju znatno veće vrijednosti vezne čvrstoće u odnosu prema površini tretiranoj Erbijevim laserom (24), 
and lead to impossibility of ensuring a quality connection. Another reason for poor bonding is the contamination and deposition of alumina particles on the ceramic surface. Ustun et al. have claimed that the surface treatment affects surface roughness and stated that sandblasting achieves significantly higher values of bond strength compared to the surface treated with Erbi laser (24). The abovementioned facts have been confirmed by this research. The abovementioned authors prefer sandblasting over the application of Er: Yag lasers. Bond quality tests between ceramics and composite cement can be carried out by tests such as aging corrosion and alike (25). Water storage leads to gradual water absorption within the composite, which can lead to hydrolytic degradation and consequently to bond weakening between the ceramic and the composite cement; silane bond hydrolysis is likely to occur $(26,27)$.

Numerous authors concur that the optimum bond between composite cement and glass-ceramics varies for different ceramic systems. It cannot be expected that a single procedure will be universal for all-ceramic materials. This realization is crucial since new ceramic materials of different compositions and microstructures will appear on the market.

All the above-named procedures require micromechanical locking on the joint surface and a chemical bond between the joint surfaces; therefore it is necessary to intervene in some way in the surface structure of the material and/or teeth. Research on non-aggressive procedures is becoming more pronounced by modifying the surface texture and material chemical properties on the surface, which makes the surface more activated, i.e. a functional surface is created (28). The acid dissolves the ceramic surface by dissolving the glass phase. It leads to the irregular formation on the surface and increases the contact surface (29). Adhesion between ceramics and composite cement is the result of physicochemical interaction in the interface between composites (adhesives) and ceramics (substrates). The surface treatment and its topography will contribute to physical interactions of adhesion. Modifications in topography surface achieved by sandblasting will result in changes in substrate moisture, which correlates with surface energy and adhesive potential (30). Rough surface increases mechanical retention by enabling adhesive interlocking (locking) in surface irregularities (31). Unfortunately, several studies have demonstrated the possibility of ceramic surface weakening after etching, thus leading to faster fracture of the restoration (32). Although the application of dental laser for surface preparation before cementation is not exempt from difficulties, it nevertheless promises. Some tests of CW CO2 lasers impact with $10.6 \mu \mathrm{m}$ on lithium disilicate (33) and CAD-CAM ceramic (25) confirm the presence of micro-cracks and surface dissolution, as a result of the laser thermal effect irradiation at a power higher than $10 \mathrm{~W}$ $\mathrm{CW}\left(3184.7 \mathrm{~W} / \mathrm{cm}^{2}\right)$. However, ceramics structure observations irradiated with a $10 \mathrm{~W}(14,185 \mathrm{~W} / \mathrm{cm} 2)$ pulsed Nd: YAP laser with $1340 \mathrm{~nm}$ show the presence of channels, micro-cracks, and dissolved crystals (34). High quantum radiation energy directed over a precisely defined area, over a short period, is the probable cause of an enormous energy accumulation. Micro-cracks on ceramics after $\mathrm{CO} 2$ and $\mathrm{Nd}$ : YAP što se potvrđuje i u ovom istraživanju, te preferiraju pjeskarenje u odnosu prema primjeni Er:Yag lasera. Ispitivanja kvalitete veze između keramike i kompozitnoga cementa mogu se provesti testiranjem poput starenja korodiranja i slično (25). Pohrana u vodi dovodi do postupne apsorpcije vode unutar kompozita, što može rezultirati hidrolitičnom degradacijom i posljedično slabljenjem veze između keramike i kompozitnoga cementa, što se vjerojatno događa zbog hidrolize silanske veze $(26,27)$.

Mnogobrojni autori slažu se da optimum veze između kompozitnoga cementa i staklokeramike varira kad je riječ o različitim keramičkim sustavima. Ne može se očekivati da će jedinstveni postupak biti univerzalan za sve keramičke materijale. Ta spoznaja važna je i zbog činjenice da će se na tržištu pojavljivati novi keramički materijali različitih sastava i mikrostruktura.

Svi navedeni postupci zahtijevaju mikromehaničku zaključanost na spojnoj površini i kemijsku vezu između spojnih površina, što znači da je potrebno na neki način intervenirati u strukturu površine materijala i/ili zuba. Istraživanja o neagresivnim postupcima sve su češća, modificirajući površinsku teksturu i kemijska svojstva materijala na površini, čime se površina čini aktiviranijom, odnosno stvara se funkcionalna površina (28). Kiselina rastapa površinu keramike tako što rastvara staklenu fazu i taj postupak potiče stvaranje nepravilnosti na površini, što povećava kontaktnu površinu (29). Adhezija između keramike i kompozitnoga cementa rezultat je fizikalno-kemijske interakcije u međuspoju između kompozita (adheziva) i keramike (supstrata). Doprinos fizikalnim interakcijama adheziji dat će površinska obrada i njezina topografija. Promjene u topografiji površine postignute pjeskarenjem rezultirat će promjenama u vlažnosti supstrata, što je u korelaciji s energijom površine i adhezivnim potencijalom (30). Hrapava površina povećava mehaničku retenciju omogućujući adhezivni interloking (zaključavanje) u površinskim nepravilnostima (31). Nažalost, u nekoliko studija autori su demonstrirali mogućnost slabljenja površine keramike nakon jetkanja i time brži lom nadomjestka (32). Iako primjena lasera u svrhu pripreme površina prije cementiranja nije izuzeta iz poteškoća, ipak obećava. Neka testiranja utjecaja $\mathrm{CW} \mathrm{CO}_{2}$ lasera s 10,6 $\mu \mathrm{m}$ na litij-disilikatne (33) i CAD-CAM keramike (25) potvrđuju mikropukotine i rastvaranje površine kao rezultat termičkoga učinka laserske iradijacije na snazi većoj od $10 \mathrm{~W} \mathrm{CW}\left(3184.7 \mathrm{~W} / \mathrm{cm}^{2}\right)$. Pa ipak, opservacije strukture keramike iradirane s $10 \mathrm{~W}\left(14,185 \mathrm{~W} / \mathrm{cm}^{2}\right)$ pulsnim Nd:YAP laserom s $1340 \mathrm{~nm}$ pokazuju kanaliće, mikropukotine i rastvorene kristale (34). To je vjerojatno prouzročeno visokokvantnom radijacijskom energijom usmjerenom na precizno definirano područje u kratkom razdoblju, što je stvorilo akumulaciju goleme energije. Mikropukotine na keramici nakon $\mathrm{CO}_{2}$ i Nd:YAP laserske iradijacije mogu biti u korelaciji s visokim termalnim vrijednostima, što rezultira ekstremnim fizikalnim naprezanjem i dodatnim očvršćenjem keramičke površine $(4,35)$. Er:YAG laser može se koristiti za obradu površine glinične keramike, ali je rezultat znatno slabiji nego onaj postignut jetkanjem. Razlog je možda u objašnjenju da energija proizvedena Er:YAG laserom ne može biti dobro apsorbirana u toj vrsti keramike i ne stvara se dovolj- 
laser irradiation can be correlated with high thermal values leading to extreme physical stress and additional ceramic surface hardening $(4,35)$. Er: YAG lasers can be used to treat the surface of alumina ceramics, but their result is much weaker than the one achieved by etching. The most probable explanation for this is that energy generated by the Er: YAG laser cannot be absorbed as well as in this type of ceramic, and it does not create a sufficient micro-mechanical retention (36). According to this study, some authors recommended the use of very high energy $(500 \mathrm{~mJ})$ to achieve a satisfactory retention (37). The most recent types of ultra-short pulsed lasers may achieve better results (38).

Despite the results of numerous studies, the application of lasers is still an alternative method in surface preparation in order to achieve a better connection between two surfaces in contact. Lasers modify the material surface in a relatively light and simple way. In $\mathrm{ZrO} 2$ ceramics, the laser does not form the desired roughness because these irregularities are very shallow and do not provide micromechanical retention, meaning there is no increase in bond strength. Compared to tribochemical processing, the laser is less efficient. During laser surface treatment, created clusters can stick to the melted ceramic surface, leading to quality bond impairment (39).

Er: Yag is the most commonly used laser in clinical practice. The wavelength is approximately $2940 \mathrm{~nm}$. These types of lasers make the surface irregular, which increases the micromechanical retention of the ceramic material. Lasers with longer wavelengths can damage the surface by creating cracks, thus weakening the bond (40). The findings of previously mentioned studies are contradictory and are not in line with findings of the present survey. Numerous factors such as ceramic moisture, surface roughness, binder, and chemical composition can affect the composite cement quality and stability and its bond to the ceramic surface (2). Gomes et al. thermocycled zirconium oxide ceramics samples cemented with composite cement and concluded that shear bond strength is affected by surface treatment, aging, and cement type (38). On the contrary, Subasi (41) believes that cement type has the greatest impact on shear bond strength, while Oyagüe favors pretreatment of the joint surface (42). The SEM analysis shows that the once treated surface always remains rough, and has uniform round micro retentions and shallow holes, but without microcracks. Silane contains silicon-bonded to reactive organic radicals that chemically bind to composite molecules forming siloxanes with silicon-coated surfaces. This improves the ceramic humidity (creating better contact and composite infiltration into the ceramic irregularity), protecting it from moisture and creating an acidic environment that can support the bonding mechanisms $(43,44)$.

Zirconia ceramics does not contain water, which can affect absorption of laser energy. Therefore, some studies did not find a significant increase of the micromechanical bond between cement and ceramics (45). However, Spohr et al. (46) and Usumezet et al (47) concluded that Nd:YAG laser irradiation increased both, the surface roughness and shear bond strength. Our results also revealed an increase in surface roughness and bond strength due to Nd:YAG laser irradiation. no mikromehaničke retencije (36). U suglasju s tom studijom neki autori preporučuju vrlo veliku energiju $(500 \mathrm{~mJ})$ kako bi se postigla zadovoljavajuća retencija (37). Novijim, ultrakratko pulsirajućim laserima možda će se postizati bolji rezultati (38).

Unatoč mnogobrojnim studijama može se reći da je primjena lasera još uvijek alternativna metoda u pripremi površine da bi se ostvarila kvalitetnija veza između dviju površina u dodiru. Laseri modificiraju površinu materijala razmjerno lagano i jednostavno. Laserom se na $\mathrm{ZrO}_{2}$ keramici ne potiže poželjna hrapavost jer su te neravnine vrlo plitke i ne osiguravaju mikromehaničku retenciju, što znači da nema povećanja vezne čvrstoće. U odnosu prema termokemijskoj obradi, laser je manje učinkovit. Tijekom laserske obrade površine stvaraju se nakupine koje se mogu zalijepiti za otopljenu površinu keramike te tako dodatno narušiti kvalitetu veze (39).

Najčešće korišten laser u kliničkoj praksi jest Er:Yag. Valna dužina je oko $2940 \mathrm{~nm}$, i što je vrlo važno, radi u pulsnom modu. Taj laser čini površinu nepravilnom, što povećava mikromehaničku retenciju keramičkoga materijala. Laser $s$ većom valom dužinom može oštetiti površinu jer tvori pukotine i tako oslabljuje vezu (40), što je u suprotnosti s rezultatima ovog istraživanja. Mnogobrojni čimbenici poput vlažnosti keramike, površinske hrapavosti, veznoga sredstva i kemijskoga sastava mogu utjecati na kvalitetu i stabilnost kompozitnoga cementa i njegove veze s površinom keramike (2). Gomes i suradnici (38) termociklirali su uzorke cirkonijoksidne keramike učvršćene kompozitnim cementima i zaključili da na veznu čvrstoću utječe obrada površine, starenje i vrsta cementa. Za razliku od njih, Subasi (41) smatra da najveći utjecaj na veznu čvrstoću ima vrsta cementa, a Oyagüe favorizira predpripremu spojne površine (42). SEM analiza pokazuje da jednom tretirana površina ostaje uvijek hrapava, ima ujednačene okrugle mikroretencije i plitke rupice, ali bez mikropukotina. Silan sadržava silicij spojen s reaktivnim organskim radikalima koji se kemijski vežu s molekulama kompozita stvarajući siloksansku mrežu s površinama presvučenima silicijem. Tako se poboljšava vlažnost keramike (nastaje bolji kontakt i infiltracija kompozita u nepravilnosti u keramici), štiteći od vlage i kreirajući kiseli okoliš koji može podupirati vezne mehanizme $(43,44)$.

Keramika od cirkonija ne sadržava vodu i to može utjecati na apsorpciju laserske energije. Stoga u nekim istraživanjima nije otkriveno znatno povećanje mikromehaničke veze između cementa i keramike (45). No Spohr i suradnici (46) te Usumezet i suradnici (47) zaključili su da zračenje Nd:Yag laserom povećava i hrapavost površine i čvrstoću vezivanja. Naši su rezultati također pokazali povećanu hrapavost površine i čvrstoću vezivanja kao posljedicu zračenja laserom Nd:Yag. 


\section{Conclusions}

Under the limitations of this study, the Nd:YAG irradiation with silanization could be used as pretreatment for providing greater shear bond strength of self-adhesive resin cement to zirconium reinforced lithium disilicate. The pretreatment with ER.YAG irradiation did not increase the bond strength compared to the conventional pretreatment protocol.

\section{Conflict of interest}

The authors declared no conflict of interest

Author's contribution: A.C., D.K., I.B. - made a research plan, preparation of samples, and they performed laboratory testing; A.C., D.K., I.B., D.N.V., J.K., B.B. - searched the literature, analyzed the obtained results and participated in manuscript writing.

\section{Zaključak}

Uzimajući u obzir ograničenja ovog istraživanja, Nd:Yag lasersko zračenje u kombinaciji sa silanizacijom moglo bi se koristiti kao predtretman u svrhu osiguravanja bolje čvrstoće vezivanja samoadherirajućega smolastoga cementa i litij-disilikatne keramike ojačane cirkonijevim dioksidom. Predtretman Er: YAG laserom nije povećao čvrstoću vezivanja u usporedbi s konvencionalnim protokolom obrade.

\section{Sukob interesa}

Autori nisu bili u sukobu interesa.

Doprinos autora: A. C., D. K., I. B. - pripremili plan istraživanja i uzorke te obavili laboratorijska ispitivanja; A. C., D. K., I. B., D. N. V., J. K., B. B. - pretraživali literaturu, analizirali dobivene rezultate i sudjelovali u pisanju rukopisa

\section{Sažetak}

Cilj: Analizirati utjecaj različitih površinskih obrada litij-disilikatne keramike ojačane cirkonijevim dioksidom na veznu čvrstoću samoadherirajućega smolastoga cementa. Materijali i metode: Osamdeset i četiri litij-disilikatna uzorka diska Vita suprinity (Vita Zahnfabrick, Bad Säckingen, Njemačka) ojačana cirkonijevim dioksidom, veličine $14 \times 12 \times 2 \mathrm{~mm}$, proizvedena su prema preporukama proizvođača. Uzorci su inkorporirani u akrilatne blokove i podijeljeni prema vrsti površinskog tretmana u sedam skupina ( $n=12$ / svaka): skupina 1. - 10-postotna fluorovodična kiselina; skupina 2. - silanizacija; skupina 3. - fluorovodična kiselina i silanizacija; skupina 4. - pjeskarenje i silanizacija; skupina 5. Er: YAG laser + silanizacija; skupina 6. - Nd: YAG laser + silanizacija; kontrolna skupina u kojoj uzorci nisu obrađivani. Za testiranje smične čvrstoće napravljeni su diskovi od kompozita (Filtek Bulk fill, 3M ESPE, St.Paul, Minnesota, SAD) okruglog oblika promjera 3,5 mm, te su pričvršćeni na površinu keramičkog uzorka kompozitnim cementom (RelyX U200 Automix, 3M ESPE, Neuss, Njemačka). Nakon cementiranja kompozitnog diska na uzorak, uzorci su podvrgnuti testu snage smične sile od $10 \mathrm{~N} \mathrm{uz}$ stress rate od $1 \mathrm{MPa} / \mathrm{s}$. Kako bi se ustanovila priroda loma (adhezivni, kohezivni ili adhezivno/kohezivni), slomljeni uzorci pregledani su pod stereomikroskopom. Za usporedbu vrijednosti obilježja snage vezivanja između različitih vrsta materijala korišteni su ANOVA i Tukeyev test. Svim testovima razina značajnosti bila je $\alpha=0,05$. Rezultati: Značajna je razlika u veznoj čvrstoći samoadherirajućega cementa na dentalnu litij-disilikatnu keramiku ojačanu cirkonijevim dioksidom nakon različitih protokola pripreme $(p<0,05)$. Zabilježena je značajno veća snaga vezivanja nakon tretmana litij-disilikatne keramike ojačane cirkonijevim dioksidom postupkom silanizacije, pjeskarenja + silanizacije i Nd:YAG laserom + silanizacija u odnosu prema kontrolnoj skupini. Postoji statistički značajno veća vezna čvrstoća samoadherirajućega cementa nakon predtretmana litij-disilikatne keramike laserom Nd:YAG + silanizacijom u usporedbi s laserom Er:YAG + silanizacijom $(p<0,05)$. U kontrolnoj skupini i u skupini pjeskarenje + silanizacija te u skupinama s laserom prevladava adhezivni lom, a u ostalima mješoviti. Zaključak: Uzimajući u obzir ograničenja ovog istraživanja, Nd: Yag lasersko zračenje u kombinaciji sa silanizacijom moglo bi se koristiti kao predtretman u svrhu osiguravanja bolje čvrstoće vezivanja samoadherirajućega smolastoga cementa i litij-disilikatne keramike ojačane cirkonijevim dioksidom.
Zaprimljen: 10. svibnja 2021.

Prihvaćen: 22. kolovoza 2021.

Adresa za dopisivanje izv. prof. dr. sc. Andreja Carek Sveučilište u Zagrebu Stomatološki fakultet Zavod za fiksnu protetiku Gundulićeva 5, 10000 Zagreb, Hrvatska acarek@sfzg.hr

MeSH pojmovi: samostvrdnjavajuće stomatološke smole; površinska svojstva; prionjivost; posmična čvrstoća

Ključne riječi: lasersko zračenje, površinska obrada, čvrstoća vezivanja, hrapavost površine, litij-disilikatna keramika ojačana cirkonijevim dioksidom, samoadherirajući smolasti cement

\section{References}

1. Verissimo AH, Tribst JPM, Leite FPP. Effect of hydrofluoric acid concentration and etching time on resin-bond strength to different glass-ceramics. Braz Oral Res. 2019;33:e041.

2. Trajtenberg CP, Pereira R, Powers JM. Resin bond strength and micromorphology of human teeth prepared with an Erbium:YAG laser. Am J Dent. 2004 Oct;17(5):331-6.

3. Shiu P, Souza-Zaroni WC, Eduardo CP, Youssef MN. Effect of felspathic ceramic surface treatments on bond strength to resin cement. Photomed Laser Surg. 2007 Aug;25(4):291-6.

4. da Silva Ferreira S, Hanashiro FS, de Souza-Zaroni WC, Turbino $M L$, Youssef MN. Influence of aluminum oxide sandblasting associated with Nd:YAG or Er:YAG lasers on shear bond strength of a feldspathic ceramic to resin cements. Photomed Laser Surg. 2010 Aug;28(4):471-5.

5. Paranhos M, Burnett Jr LH, Magne P. Effect Of Nd: YAGlaser and $\mathrm{CO} 2$ laser treatment on the resin bond strength tozirconia ceramic. Quintessence Int. 2011 Jan;42(1):79-89.

6. Akyil MS, Uzun IH, Bayindir F. Bond strength of resincement to yttrium-stabilized tetragonal zirconia ceramictreated with airabrasion, silica coating, and laser irradiation. Photomed Laser Surg. 2010 Dec;28(6):801-8.
7. Holand W, Schweiger RL, Frank M, Rheinberger V. A comparison of the microstructure and properties of the IPS Empress 2 and the IPS empress glass-ceramics. J Biomed Mater Res. 2000;53(4):297-303.

8. Della Bona A, Mecholsky JJ Jr., Anusavice KJ. Fracture behavior of lithia disilicate and leucite-based ceramics. Dent Mater. 2004 Dec;20(10):956-62.

9. Ural C, Kalyoncuoglu E, Balkaya V. The effect of different power outputs of carbon-dioxide laser on bonding between zirconia ceramic surface and resin cement. Acta Odontol Scand. 2012 Dec;70(6):541-6.

10. Akin H, Tugut F, Emine Akin G, Guney U, Mutal B. Eect of ER: Yag laser application on shear bond strength and microleakage between resin cements and Y-TZP ceramics. Lasers Med Sci. 2012 Mar;27(2):333-8.

11. Giordano R, McLaren EA. Ceramics overview: Classification by microstructure and processing methods. Compend Contin Educ Dent. Nov-Dec 2010;31(9):682-4, 686, 688 passim; quiz 698, 700.

12. Albakry M, Guazzato M, Swain MV. Fracture toughness and hardness evaluation of three pressable all-ceramic dental materials. J Dent. 2003 Mar;31(3):181-8. 
13. Tian T, Tsoi JK, Matinlinna JP, Burrow MF. Aspects of bonding between resin luting cements and glass ceramic materials. Dent Mater. 2014 Jul;30(7):e147-62.

14. Addison O, Marquis PM, Fleming GJ. Resin strengthening of dental ceramics - the impact of surface texture and silane. J Dent. 2007 May;35(5):416-24. Menezes FC, Borges GA,

15. Valentino TA, Oliveira MA, Turssi CP, Correr-Sobrinho I. Effect of surface treatment and storage on the bond strength of different ceramic systems. Braz Oral Res. Apr-Jun 2009;23(2):119-23.

16. El Zohairy AA, De Gee AJ, Hassan FM, Feilzer AJ. The effect of adhesives with various degrees of hydrophilicity on resinceramic bond durability. Dent Mater. 2004 Oct;20(8):778-87.

17. Della Bona A, Anusavice KJ, Mecholsky Jr JJ. Failure analysis of resin composite bonded to ceramic. Dent Mater. 2003 Dec;19(8):693-9.

18. Pashley DH, Carvalho RM, Sano H, Nakajima M, Yoshiyama M, Shono Y, et al. The microtensile bond test: a review. J Adhes Dent. Winter 1999;1(4):299-309.

19. Abdullah AO, Muhammed FK, Yu H, Pollington S, Xudong S, Liu Y. The impact of laser scanning on zirconia coating and shear bond strength using veneer ceramic material. Dent Mater J. 2019 Jun 1;38(3):452-463.

20. Filho AM, Vieira LC, Araujo E, Monteiro Jr. S. Effect of different ceramic surface treatments on resin microtensile bond strength. J Prosthodont. 2004 Mar;13(1):28-35.

21. Soderholm KJ, Shang SW. Molecular orientation of silane at the suraface of colloidal silica. J Dent Res. 1993 Jun;72(6):1050-4.

22. Amaral R, Ozcan M, Bottino MA, Valandro LF. Microtensile bond strength of a resin cement to glass infiltrated zirconia-reinforced ceramic: the effect of surface conditioning. Dent Mater. 2006 Mar;22(3):283-90.

23. Shimada Y, Yamaguchi S, Tagami J. Micro-shear bond strength of dual-cured resin cement to glass ceramics. Dent Mater. 2002 Jul;18(5):380-8.

24. Ustun O, Akar T, Kirmali O. A comparative study of laser irradiation versus sandblasting in improving the bond strength of titanium abutments. Photobiomodul Photomed Laser Surg. 2019 Aug;37(8):465-472.

25. El Zohairy AA, De Gee AJ, Hassan FM, Feilzer AJ. The effect of adhesives with various degrees of hydrophilicity on resinceramic bond durability. Dent Mater. 2004 Oct;20(8):778-87.

26. Brentel AS, Ozcan M, Valandro LF, Alarca LG, Amaral R, Bottino MA. Microtensile bond strength of a resin cement to feldpathic ceramic after different etching and silanization regimens in dry and aged conditions. Dent Mater. 2007 Nov;23(11):1323-31.

27. Stokes AN, Hood JAA, Tidmarsh BG. Effect of 6-month water storage on silane-treated resin/porcelain bonds. J Dent. 1988 Dec;16(6):294-6.

28. Thompson JY, Stoner BR, Piascik JR, Smith R. Adhesion/cementation to zirconia and other non-silicate ceramics: Where are we now. Dent Mater. 2011 Jan;27(1):71-82.

29. Della Bona A, Borba M, Benetti P, Pecho OE, Alessandretti R, Mosele JC, et al. Adhesion to dental ceramics. Curr Oral Health Rep. 2014;1:232-38.

30. Saracoglu A, Cura C, Cotert HS. E. Effect of various surface treatment methods on the bond strength on the heat-pressed ceramic samples. J Oral Rehabil. 2004 Aug;31(8):790-7.

31. Blatz MB, Sadan A, Kern M. Resin-ceramic bonding - A review of the literature. J Prosthet Dent. 2003 Mar;89(3):268-74.
32. Rocca JP, Fornaini C, Brulat-Bouchard N, Bassel Seif S, DarqueCeretti E. $\mathrm{CO}_{2}$ and $\mathrm{Nd}$ :YAP laser interaction with lithium disili cate and Zirconia dental ceramics: A preliminary study. Opt Laser Technol. 2014;57:216-23.

33. El Gamal A, Fornaini C, Rocca JP, Muhammad OH, Medioni $\mathrm{E}$ Cucinotta $A$, et al. The effect of $\mathrm{CO}_{2}$ and $\mathrm{Nd}$ :Yap lasers on CAD CAM ceramics: SEM, EDS and thermal studies. Laser Technol. 2014;25:27-34.

34. Liu L, Liu S, Song X, Zhu Q, Zhang W. Effect of Nd:Yag laser irradiation on surface properties and bond strength of zirconia ceramics. Lasers Med Sci. 2015 Feb;30(2):627-34.

35. Sadeghi M, Davari A, Abolghasami Mahani A, Hakimi H. Influence of different power outputs of Er:YAG laser on shear bond strength of a resin composite to feldspathic porcelain. J Dent (Shiraz). 2015 Mar;16(1):30-6.

36. Shiu P, De Souza Zaroni WC, Eduardo Cde P, Youssef MN. Effect of feldpathic ceramic surface treatments on bond strength to resin cement. Photomed Laser Surg. 2007 Aug;25(4):291-6.

37. Erdur EA, Basciftci FA. Effect of Ti:Sapphire-femtosecond lase on the surface rougness of ceramics. Lasers Surg Med. 2015 Dec;47(10):833-8.

38. Gomes AL, Ramos JC, Santos-del Riego S, Montero J, Albaladejo A. Thermocycling effect on microshear bond strength to zirconia ceramic using Er:Yag and tribochemical silica coating as surface conditioning. Lasers Med Sci. 2015 Feb;30(2):787-95.

39. Akin H, Ozkurt Z, Kimali O,Kazazoglu E, Ozdemir AK. Shear bond strength of resin cement to zirconia ceramic after aluminium oxide sandblasting and various laser treatments. Photomed Laser Surg. 2011 Dec;29(12):797-802

40. Yang B, Lange-Jensen HC, Scharnberg M, Wolfart S, Ludwig K, Adelung R, Kern M. Influence of saliva contamination on zirconia ceramic bonding. Dent Mater. 2008 Apr;24(4):508-13.

41. Subasi MG, Inan O. Evaluation of the topographical surface changes and roughness of zirconia after different surface treatments. Lasers Med Sci. 2012 Jul;27(4):735-42.

42. Oyagüe RC, Osorio R, da Silveira BL, Toledano M. Comparison of bond stability between dual-cure resin cements and pretreated glass-infiltrated aluminia ceramics. Photomed Laser Surg. 2011 Jul;29(7):465-75

43. Matinlinna JP, Vallitu PK. Bonding of resin composites to etchable ceramic surfaces: an insight overview of the chemical aspects on surface conditioning. J Oral Rehabil. 2007 Aug;34(8):622-30.

44. Mehmeti B, Kelmendi J, Shahiqi D, Azizi B, Jakovljevic S, Haliti T, et al.. Comparison of Shear Bond Strength Orthodontic Brackets Bonded to Zirconia and Lithium Disilicate Crowns Table 1. Data normality testing for shear bond strength. Acta Stomatol Croat. 2019 Mar;53(1):17-27.

45. Liu L, Liu S, Song X, Zhu Q, Zhang W. Effect of Nd: YAGlaser irradiation on surface properties and bond strength ofzirconia ceram ics. Lasers Med Sci. 2015 Feb;30(2):627-34.

46. Spohr AM, Borges GA, Júnior LH, Mota EG, Oshima HM.Surface modification of In-Ceram Zirconia ceramic byNd:YAG laser, Rocatec system, or aluminum oxidesandblasting and its bond strength to a resin cement. Photomed Laser Surg. 2008 Jun;26(3):203-8.

47. Usumez A, Hamdemirci N, Koroglu BY, Simsek I, ParlarO. Bond strength of resin cement to zirconia ceramic withdifferent surface treatments. Lasers Med Sci. 2013 Jan;28(1):259-66. 